\title{
A deformed alkaline igneous rock-carbonatite complex from the Western Sierras Pampeanas, Argentina: Evidence for late Neoproterozoic opening of the Clymene Ocean?
}

\author{
C. Casquet $^{\text {a: }}$, R.J. Pankhurst ${ }^{\text {b. C. Galindo }}$, C. Rapela ${ }^{\text {, }}$, C.M. Fanning ${ }^{\text {d }}$. E. Baldo ${ }^{\text {e }}$, \\ J. Dahlquist ${ }^{\mathrm{e}}$, J.M. González Casado ${ }^{\mathrm{f}, 1}$, F. Colombo ${ }^{\mathrm{e}}$ \\ a Dpto. Petrología y Geoquímica, Fac. Ciencias Geológicas, Inst. Geología Económica (CSIC, Universidad Complutense), 28040 Madrid, Spain \\ b British Geological Survey, Keyworth, Nottingham NG12 5GG, UK \\ 'Centro de Investigaciones Geológicas, Universidad de La Plata, 1900 La Plata, Argentina \\ ¿ Research School of Earth Sciences, The Australian National University, Canberra, ACT 200. Australia \\ ' CICTERRA (Conicet-Universidad Nacional de Córdoba). Vélez Sarsfield 1611. 5016 Córdoba, Argentina \\ f Dpto. de Geología y Geoquímica, Universidad Autónoma, 28049 Madrid, Spain
}

Keywords:

DARCs

Syenite

U-Pb SHRIMP zircon dating

Gondwana

Rodinia

\begin{abstract}
A B S T R A C T
A deformed ca. $570 \mathrm{Ma}$ syenite-carbonatite body is reported from a Grenville-age (1.0-1.2 Ga) terrane in theSierra de Maz, one of the Western Sierras Pampeanas of Argentina. This is the first recognition of such a rock assemblage in the basement of the Central Andes. The two main lithologies are coarse-grained syenite (often nepheline-bearing) and enclave-rich fine-grained foliated biotite-calcite carbonatite. Samples of carbonatite and syenite yield an imprecise whole rock Rb-Sr isochron age of $582 \pm 60 \mathrm{Ma}$ (MSWD $=1.8$; $\mathrm{Sri}=0.7029$ ); SHRIMP U-Pb spot analysis of syenite zircons shows a total range of ${ }^{206} \mathrm{~Pb}-{ }^{238} \mathrm{U}$ ages between 433 and $612 \mathrm{Ma}$, with a prominent peak at 560-580 Ma defined by homogeneous zircon areas. Textural interpretation of the zircon data, combined with the constraint of the $\mathrm{Rb}-\mathrm{Sr}$ data suggest that the carbonatite complex formed at ca. $570 \mathrm{Ma}$. Further disturbance of the U-Pb system took place at $525 \pm 7 \mathrm{Ma}$ (Pampean orogeny) and at ca. 430-440 Ma (Famatinian orogeny) and it is concluded that the Western Sierras Pampeanas basement was joined to Gondwana during both events. Highly unradiogenic ${ }^{87} \mathrm{Sr}{ }^{86} \mathrm{Sr}$ values in calcites $(0.70275-0.70305)$ provide a close estimate for the initial $\mathrm{Sr}$ isotope composition of the carbonatite magma. Sm-Nd data yield $\varepsilon \mathrm{Nd}_{570}$ values of +3.3 to +4.8 . The complex was probably formed during early opening of the Clymene Ocean from depleted mantle with a component from Meso/Neoproterozoic lower continental crust.
\end{abstract}

\section{Introduction}

The association of alkaline igneous rocks (particularly nepheline syenites) with carbonatites is common in continental rift settings (Bailey, 1977, 1992; Bell, 1989; Burke et al., 2003), where they are sometimes referred to by the acronym ARCs (alkaline rock-carbonatite complexes). Deformed, i.e., variably foliated concordant lenses (DARCs) are a special case, in which they apparently match ancient sutures in basement regions (Burke et al., 2003). Since sutures are indicative of orogenic continental collision at the end of a Wilson cycle, one interpretation of these deformed rock associations is that they represent earlier rift-related ARC assemblages that eventually became involved in the collision zone (Burke and Khan, 2006). An alternative interpretation, based on geochronological constraints, is that they formed during synorogenic extension related to continental orogeny, e.g., along the Dahomeyide suture zone of western Africa (Attoh et al., 2007). In a recent synthesis of the many 650-500 Ma alkaline rocks and carbonatites related to the amalgamation of Gondwana, Veevers (2003, 2007) favoured the location of these and other alkaline associations at releasing bends along transcurrent faults driven by collisional oblique stresses and during post collisional relaxation. Vaughan and Scarrow (2003) outlined a model for the generation of potassic mafic and ultramafic magmas by transtension of metasomatized mantle.

We describe here the case of a Neoproterozoic deformed syenite-carbonatite body intruded into a Grenville-age $(1.0-1.2 \mathrm{Ga})$ terrane in the Sierra de Maz, one of the Western Sierras Pampeanas of Argentina. After Rodinia break-up this terrane was involved in 
an Early Paleozoic collision, the Pampean orogeny, a stage in the amalgamation of SW Gondwana that involved subduction-related granite magmatism and high-grade metamorphism, largely to the east of the Western Sierras Pampeanas (Rapela et al., 2007). It is thus is a good test case for geotectonic models for deformed ARC formation. Moreover, to our knowledge this is the first recognition of such a rock assemblage of Precambrian age in the basement of the Central Andes, which could prove to be of economic importance. Carbonatite and a diversity of alkaline silicate rocks and related hydrothermal alteration products of Cretaceous age are however well known from elsewhere in the Central Andes and its eastern foreland (e.g., Schultz et al., 2004, and references therein). Geochronological constraints and isotope geochemistry suggest that the first mode of deformed ARC formation above, i.e., early during the Pampean Wilson cycle in the late Neoproterozoic, probably applies in the case of the Maz syenite-carbonatite body. Moreover syenite and carbonatite magmas were coeval and were mainly fed from a depleted mantle source, probably with a minor contribution from a poorly radiogenic continental crust of Grenville age.

\section{Geological and paleogeographical setting}

The Sierras Pampeanas of Argentina are elongated blocks of pre-Andean crystalline basement that were exposed to erosion by tilting during Cenozoic Andean tectonics (Fig. 1). Three metamorphic and igneous belts have been distinguished (for a review, see Rapela et al., 1998a, 2002)(Fig. 1a): (1) theolder is of 'Grenville' age, ca. 1.0-1.2 Ga, and crops out in the Western Sierras Pampeanas; (2) the Pampean belt is of Early Cambrian age, between 530 and 515 Ma, and crops out in the Eastern Sierras Pampeanas; (3) the Famatinian belt of Ordovician age, ca. 490-430 Ma, is located between the former two and is the best preserved. Famatinian metamorphism, deformation and magmatism overprint with varied extent and intensity the Grenvillian and Pampean belts. The Sierra de Maz (Fig. 1b) is one of the Western Sierras Pampeanas where Grenvilleage metamorphic and igneous rocks have been recognized (Porcher et al., 2004; Casquet et al., 2005, 2006, 2008). Other larger outcrops of Grenville-age rocks exist in the Sierra de Pie de Palo (see review by Ramos, 2004; Baldo et al., 2006) and Umango (Varela et al., 2003) (Fig. 1).

Paleogeographic reconstructions and dynamic interpretations of the proto-Andean margin of Gondwana in the Mesoproterozoic to Ordovician time span have been strongly stimulated over the past 15 years by the hypothesis of allochthoneity of the Precordillera terrane (e.g., Vaughan and Pankhurst, 2008). According to most supporters of the hypothesis, this terrane consists of a Grenvilleage basement that crops out in the Western Sierras Pampeanas and a non-metamorphic Early Cambrian to Middle Ordovician passive margin cover sequence, i.e., the Argentine Precordillera (Fig. 1) (for reviews see Thomas and Astini, 2003; Ramos, 2004). In this paradigm, the Precordillera terrane is an exotic terrane rifted away from the Ouachita embayment in the Appalachian margin of eastern Laurentia in the Early Cambrian that collided with the proto-Andean margin of Gondwana in the Ordovician to produce the Famatinian orogeny (Thomas, 1991; Thomas and Astini, 1996). However, whether the Grenvillian outcrops in Western Sierras Pampeanas are part of the exotic terrane or not has also been questioned (Galindo et al., 2004; Rapela et al., 2005; Casquet et al., 2008). In a recent contribution Rapela et al. (2007) suggested that after initial break-up of Rodinia the Western Sierras Pampeanas Grenville-age basement was part of a larger continental mass embracing the Mesoproterozoic central and northern Arequipa-Antofalla craton (Peru), and the Amazonia craton(Brazil). These continental domains coalesced during the Sunsas (Grenville- age) orogeny ( Loewy et al., 2004; Tohver et al., 2002, 2004; Casquet et al., 2008). This large continent collided obliquely with the Rio de la Plata and Kalahari cratons to the east (present coordinates) to produce the Pampean orogeny in the early Cambrian, with the disappearance of the intervening Clymene Ocean (Trindade et al., 2006).

\section{Field description}

The Maz deformed syenite-carbonatite complex forms a body ca. 4-km long and of variable thickness (max. $120 \mathrm{~m}$ ), striking $340-345^{\circ}$ along the eastern margin of the Sierra de Maz and dipping $65-70^{\circ}$ E. (Figs. 2 and 3a). Host rocks are: (1) hornblende-biotitegarnet gneisses and biotite-garnet gneisses with some interleaved quartzites and marbles; (2) ortho-amphibolites, metagabbros and local meta-peridotites; (3) massif-type anorthosites of $1070 \pm 41 \mathrm{Ma}$ (Casquet et al., 2005) and a variety of coeval granitic orthogneisses. Host rocks to the complex (Fig. 1b) belong to the Maz Central Domain (Casquet et al., 2008), which underwent granulite facies metamorphism at ca. $1.2 \mathrm{Ga}$ and retrogression under amphibolite facies conditions at $431 \pm 40 \mathrm{Ma}$ (Casquet et al., 2006, 2008). The intrusion is largely concordant, but locally discordant, to the foliation of the host rocks (Fig. 2).

Homogeneous medium- to coarse-grained syenite and finegrained foliated biotite carbonatite are the two main lithologies forming the body. They do not show a clear internal arrangement, syenite ranging from elongated bodies tens of metres long down to few centimetre-size spheroidal enclaves in the carbonatite. Carbonatite foliation wraps around the syenite bodies that are locally foliated as well (Fig. 3b). Besides syenite, the carbonatite hosts a number of other types of enclaves, notably large (up to several centimetres) isolated crystals of albite and biotite, coarse-grained mafic enclaves, and enclaves of the host gneisses and amphibolites with the internal foliation in places at a high angle to the carbonatite foliation (Fig. 3c). Enclaves are rounded to sub-angular and vary from well- to poorly sorted in terms of size from place to place, and can be locally very abundant, giving the outcrop a breccia-like aspect (Fig. 3d). Enclaves of an earlier carbonatite (also with enclaves) can be found within a younger carbonatite. Variability in the number and sorting of the enclaves suggests that their incorporation in the carbonatite magma was a multi-stage process (Fig. 3e). The syenites contain visible pinkish zircon megacrysts that can attain few centimetre size (Fig. 3f), a feature also recognized incarbonatite-syenitebodies elsewhere(Ashwal et al., 2007). Coarse-grained calcite veins and interstitial calcite are locally found in syenites.

\section{Petrography and mineralogy}

The carbonatite consists of calcite, 10-30\% modal biotite, abundant anomalous biaxial apatite, and minor magnetite, zircon, very scattered U-rich pyrochlore, and columbite. Compositionally the calcite has up to 1.3 wt.\% SrO, 2.5 wt.\% FeO, and 0.41 wt.\% $\Sigma$ LREE (Table 1 and microprobe data in the data repository; see below). Electron microprobe analyses of the biotite show an average Fe\# value $[\mathrm{Fe} /(\mathrm{Mg}+\mathrm{Fe})]$ of 0.74 and $\mathrm{Al}^{\mathrm{IV}}=2.643-2.748$ a.f.u.; the apatite has up to $2.76 \mathrm{wt} . \% \mathrm{~F}$, the pyrochlore $18.60-30.23 \mathrm{wt} . \% \mathrm{UO}_{2}$ and the columbite $\mathrm{Nb} /(\mathrm{Nb}+\mathrm{Ta})=0.98$. Calcite crystals are fine-grained granoblastic with a slight preferred orientation and narrow straight twins. Lattice-preferred orientation is weak but relics of larger strained crystals of calcite are preserved within the foliated granoblastic groundmass, suggesting that the latter probably arose by recrystallization of former coarser-grained, probably primary, carbonate crystals. Groundmass biotite is found as individual plates 


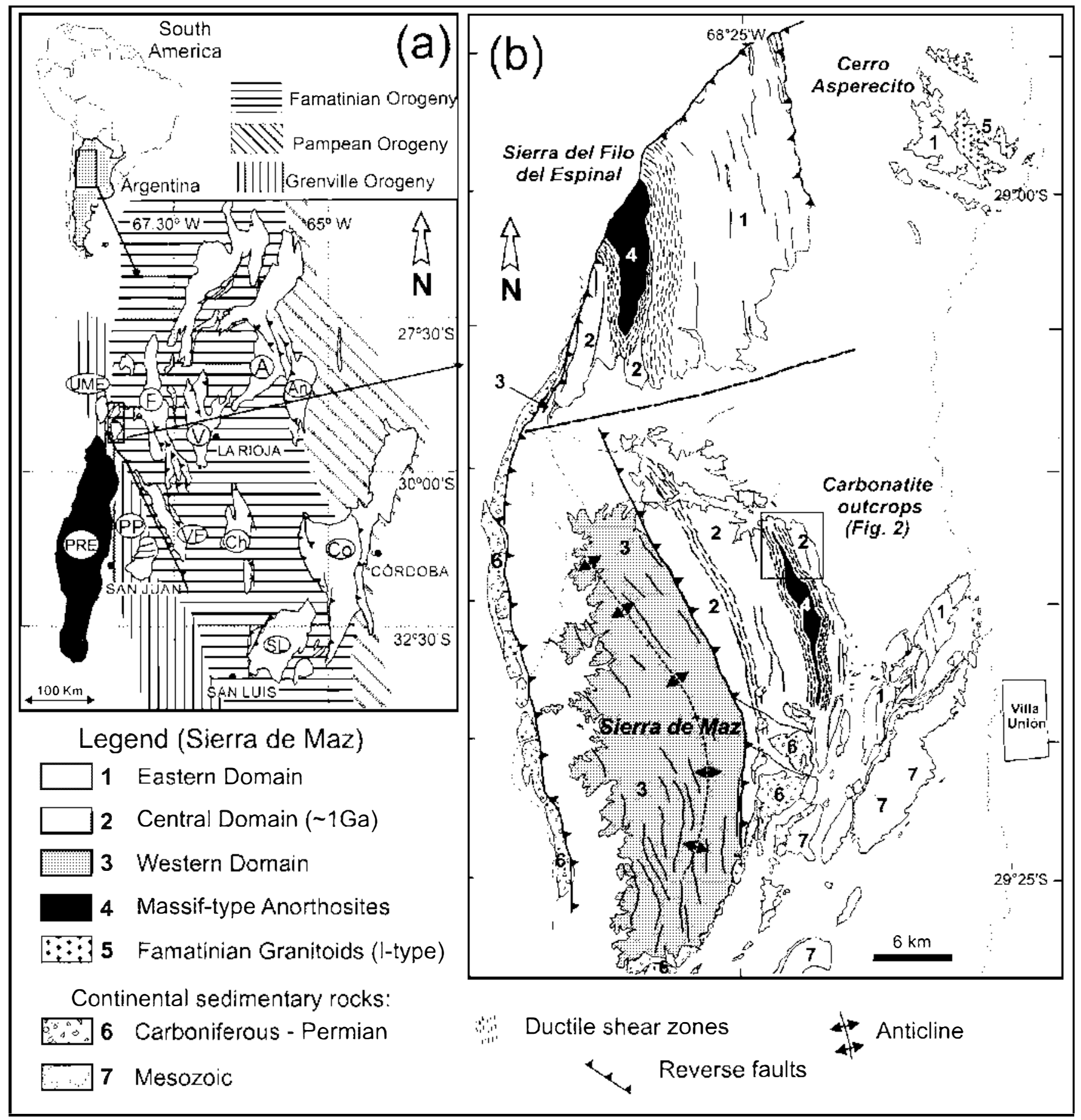

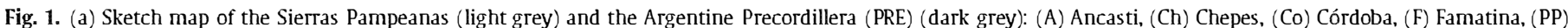

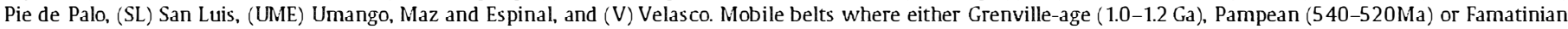

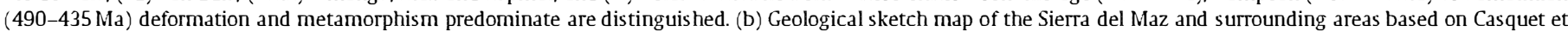
al. (2006). The box indicates the location of the study area.

but more commonly as fine-grained recrystallized aggregates, often as rims on isolated rounded albite crystals or larger albite syenite spheroids. The visible foliation largely results from preferred orientation of biotite.

The syenites are coarse-grained rocks that are locally foliated. They consist of albite : $\mathrm{b}_{95.0-97.3} \mathrm{An}_{2.2-2.6} \mathrm{Or}_{0.9-2.5}$ ) and biotite chemically similar to that in the carbonatite (Fe\#=0.83). Subordinate microcline is found at albite grain boundaries, as either replacemenc or exsolution. Undulose extinction and deformation bands in albite, and bending and kinking in biotite, are common in non-foliated varieties. K-rich nepheline ( $\left.\mathrm{Ks}_{21}-22\right)$, variably converted to a fine-grained micaceous aggregate, was found in several samples. Accessory minerals are zircon, anomalous biaxial apatite and minor pyrochlore. Secondary minerals in the syenites are calcite, muscovite-sericite after K-feldspar and chlorite and epidote after biotite. Syenite spheroids within the carbonatite con- 


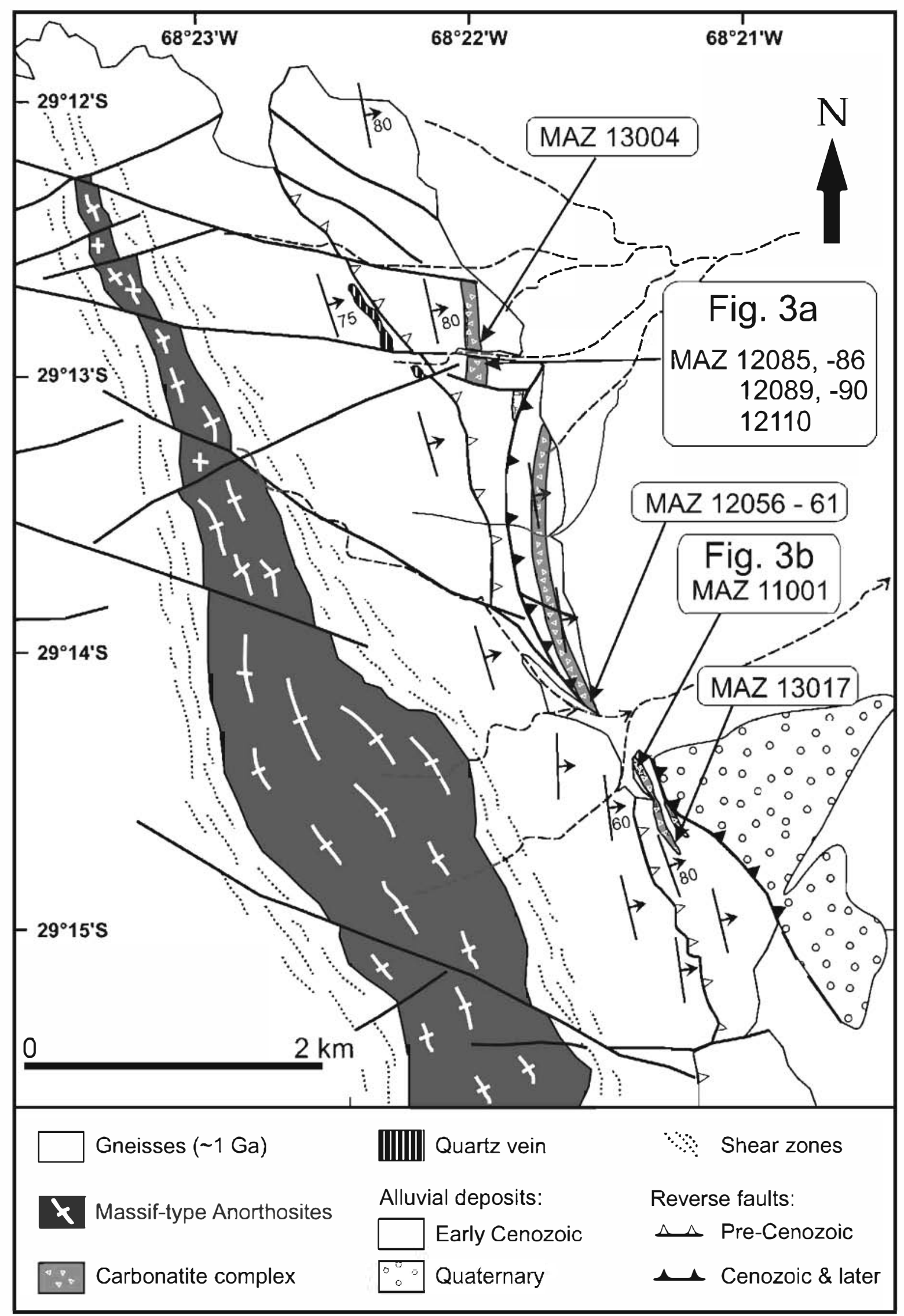

Fig. 2. Geological map of NE Sierra de Maz based on fieldwork and interpretation of satellite Raster images. 

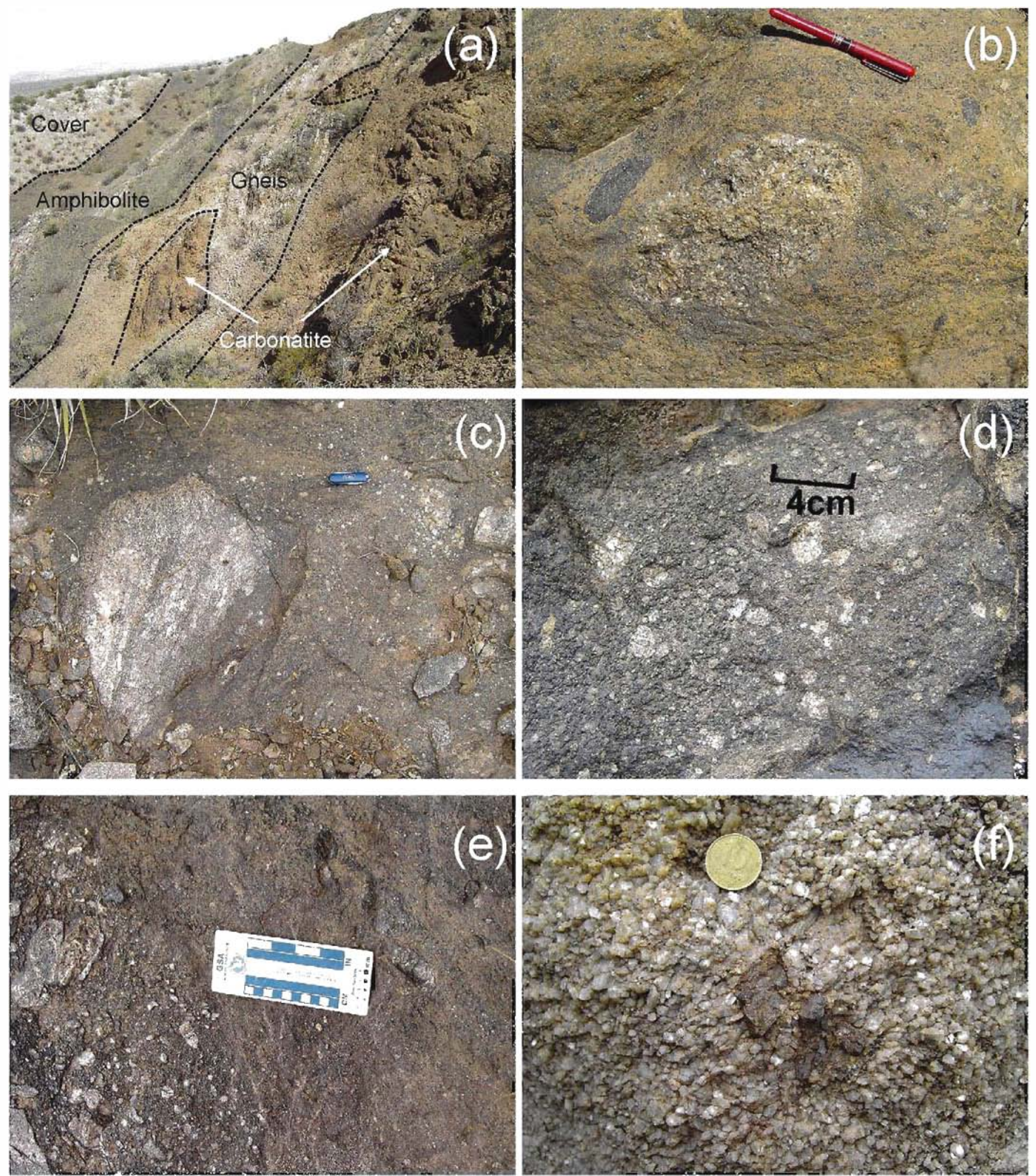

Fig. 3. (a) South-facing view of the carbonatite-syenite body at its contact with the host Grenville-age gneisses and amphibolites. A screen of gneisses is visible in the centre of the image, view width ca. $100 \mathrm{~m}$. (b) Rounded coarse-grained syenite enclave wrapped in a weakly foliated carbonatite matrix. (c) Very poorly sorted and weakly foliated breccia. Clasts consist of syenite and gneiss. The large gneiss clast is discordant to the carbonatite foliation which is parallel to the knife. (d) Carbonatite breccia. Unorientated, moderately sorted, rounded syenite clasts in carbonatite matrix. (e) Two-stage breccia. Poorly sorted syenite breccia (angular clasts), sharply bounded by a well-sorted weakly foliated microbreccia. Matrix is carbonatite in both facies. (f) Coarse-grained syenite with large euhedral zircon crystals. 
Table 1

Representative chemical analyses of the Sierra de Maz carbonatite-syenite suite

\begin{tabular}{|c|c|c|c|c|c|c|c|}
\hline \multirow[t]{2}{*}{ Samples } & \multicolumn{4}{|c|}{ Syenitic suite } & \multicolumn{2}{|l|}{ Carbonatites } & \multirow{2}{*}{$\begin{array}{l}\text { Calcite megacryst } \\
\text { MAZ-12090 }\end{array}$} \\
\hline & MAZ12110 & MAZ12085 & MAZ-12058 & MAZ-12057 & MAZ-13004 & MAZ-13017 & \\
\hline \multicolumn{8}{|c|}{ Major oxides (wt\%) } \\
\hline $\mathrm{SiO}_{2}$ & 52.59 & 58.46 & 61.14 & 64.05 & 18.18 & 19.97 & 0.04 \\
\hline $\mathrm{TiO}_{2}$ & 0.28 & 0.2 & 0.44 & 0.35 & 0.75 & 2.08 & 0 \\
\hline $\mathrm{Al}_{2} \mathrm{O}_{3}$ & 19.88 & 22.91 & 19.71 & 19.38 & 5.93 & 6.71 & 0.01 \\
\hline $\mathrm{Fe}_{2} \mathrm{O}_{3}$ & 0.46 & 0.39 & 1.99 & 0.21 & 10.38 & 13.29 & 2.74 \\
\hline $\mathrm{FeO}$ & 2.55 & 1.84 & 2.89 & 3.38 & nd & nd & nd \\
\hline $\mathrm{MnO}$ & 0.08 & 0.04 & 0.07 & 0.05 & 0.96 & 0.33 & 1.28 \\
\hline $\mathrm{MgO}$ & 0.56 & 0.29 & 0.44 & 0.23 & 2 & 3.4 & 0.42 \\
\hline $\mathrm{CaO}$ & 5.55 & 1.7 & 1.02 & 0.58 & 32.38 & 28.06 & 69.11 \\
\hline $\mathrm{Na}_{2} \mathrm{O}$ & 7.92 & 9.37 & 7.87 & 9.02 & 1.63 & 1.33 & 0.08 \\
\hline $\mathrm{K}_{2} \mathrm{O}$ & 3.77 & 2.52 & 2.79 & 2.09 & 1.23 & 2.49 & 0.01 \\
\hline $\mathrm{P}_{2} \mathrm{O}_{5}$ & 0.74 & 0.15 & 0.14 & 0.02 & 2.15 & 2.57 & 0.02 \\
\hline LOI & 4.94 & 1.41 & 0.78 & 0.67 & 24.24 & 19.61 & nd \\
\hline $\mathrm{CO}_{2}$ & nd & nd & nd & nd & 24.5 & 19.7 & nd \\
\hline $\mathrm{F}$ & nd & nd & nd & nd & 0.19 & 0.17 & nd \\
\hline $\mathrm{Cl}$ & nd & nd & nd & nd & 0.04 & 0.03 & nd \\
\hline $\mathrm{SO}_{3}$ & nd & nd & nd & nd & 0.17 & 0.07 & 0.02 \\
\hline Total S & nd & nd & nd & nd & 0.07 & 0.03 & 0 \\
\hline TOTAL & 99.32 & 99.28 & 99.28 & 100.03 & 100.14 & 100.03 & 73.73 \\
\hline \multicolumn{8}{|c|}{ Trace elements (ppm) } \\
\hline Cs & 1.1 & 2.6 & 1.1 & 0.8 & 1.2 & 1.7 & 61 \\
\hline $\mathrm{Rb}$ & 132 & 78 & 116 & 69 & 70 & 140 & 28 \\
\hline $\mathrm{Sr}$ & 1702 & 1476 & 1135 & 1120 & 6248 & 6480 & 11086 \\
\hline $\mathrm{Ba}$ & 886 & 1161 & 896 & 1041 & 635 & 2028 & 759 \\
\hline $\mathrm{La}$ & 41.8 & 11 & 3.99 & 0.8 & 287 & 463 & 1067 \\
\hline $\mathrm{Ce}$ & 94.2 & 23.4 & 9.86 & 1.3 & 581 & 901 & 2043 \\
\hline $\operatorname{Pr}$ & 11 & 2.63 & 1.27 & 0.13 & 64.3 & 96.8 & nd \\
\hline $\mathrm{Nd}$ & 40.8 & 9.81 & 5.01 & 0.44 & 249 & 380 & 856 \\
\hline $\mathrm{Sm}$ & 7.24 & 1.71 & 0.94 & 0.08 & 46.2 & 64.9 & 141 \\
\hline $\mathrm{Eu}$ & 2.47 & 0.74 & 0.58 & 0.14 & 15 & 20 & nd \\
\hline $\mathrm{Gd}$ & 6.07 & 1.57 & 0.89 & 0.08 & 36.5 & 47.2 & nd \\
\hline $\mathrm{Tb}$ & 0.87 & 0.25 & 0.13 & 0.02 & 5.83 & 7.04 & nd \\
\hline Dy & 4.23 & 1.46 & 0.71 & 0.12 & 29.4 & 33.1 & nd \\
\hline Ho & 0.69 & 0.29 & 0.15 & 0.03 & 4.83 & 5.22 & nd \\
\hline $\mathrm{Er}$ & 1.68 & 0.79 & 0.47 & 0.14 & 12.8 & 12.8 & nd \\
\hline $\mathrm{Tm}$ & 0.2 & 0.11 & 0.07 & 0.03 & 1.66 & 1.49 & nd \\
\hline Yb & 1.07 & 0.67 & 0.54 & 0.23 & 9.47 & 7.8 & 27 \\
\hline Lu & 0.14 & 0.09 & 0.1 & 0.04 & 1.34 & 1.01 & nd \\
\hline $\mathrm{U}$ & 8.31 & 12.2 & 0.77 & 0.93 & 2.65 & 1.85 & 42 \\
\hline Th & 1.44 & 4.31 & 0.33 & 0.25 & 0.93 & 4.26 & 21 \\
\hline $\mathrm{Y}$ & 17.3 & 7 & 3.6 & 1 & 150 & 157 & 393 \\
\hline $\mathrm{Nb}$ & 90.8 & 53.5 & 119 & 107 & 360 & 93.3 & nd \\
\hline $\mathrm{Zr}$ & 764 & 1920 & 1338 & 716 & 226 & 298 & 39 \\
\hline $\mathrm{Hf}$ & 19.3 & 27.4 & 25.2 & 11 & 3 & 4.1 & 37 \\
\hline $\mathrm{Ta}$ & 31 & 11 & 9.3 & 12.7 & 16.7 & 5.2 & nd \\
\hline $\mathrm{Ga}$ & 16 & 21 & 18 & 21 & 21 & 24 & nd \\
\hline $\mathrm{Ge}$ & 1 & 0.7 & 1 & 0.9 & 1.4 & 1.9 & nd \\
\hline
\end{tabular}

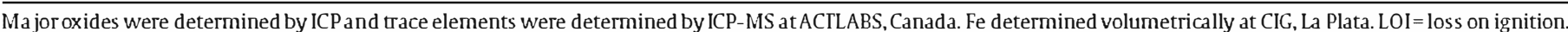

sist of an inner coarse-grained core and a continuous fine-grained mantle resembling a chilled margin, rimmed by fine-grained biotite, probably indicative of liquid inmiscibility. Foliated syenites are medium-grained and show a granoblastic orientation of albite and preferred orientation of biotite.

Besides large biotite and albite megacrysts, two types of mafic enclaves have been found in the carbonatite. One type consists of coarse-grained aegirine-augite $\left(\mathrm{Na}_{2} \mathrm{O}=5.35-5.75\right.$ wt.\%) variably converted to katophorite amphibole, albite, Fe-rich calcite and magnetite. The second type consists of coarse-grained magnetite and biotite with accessory primary calcite (included in biotite). apatite and pyrochlore.

\section{Analytical procedures}

Full chemical analyses of four syenite and two carbonatite samples were performed at ACTLABS (Canada): major oxides by ICP and trace elements by ICP-MS. Other determinations at ACTLABS were $\mathrm{Cl}$ (INAA), $\mathrm{CO}_{2}$ (COUL), $\mathrm{F}$ (FUS-ISE), and $\mathrm{S}$ (IR). $\mathrm{Fe}^{2+}$ was determined volumetrically at the Centro de Investigaciones Geológicas, La Plata. Major and trace elements of one probably relic calcite megacryst were determined by XRF (Table 1) and mineral compositions by electron microprobe at the Universidad Complutense, Madrid (Supplementary Table obtainable from the Precambrian Research Data Repository).

$\mathrm{Rb}-\mathrm{Sr}$ systematics were analysed in three samples of carbonatite, four of syenite, two vein calcites in syenites, and four enclaves in carbonatite-an aegirine mafic enclave (see below) and three megacrysts, two of biotite and one of albite. For Sm-Nd systematics five samples were analysed: two syenites and three carbonatites. Samples were crushed and powdered to $\sim 200$ mesh. For the carbonatite samples, $\mathrm{Sr}$ and $\mathrm{Nd}$ isotope composition was obtained by leaching $200 \mathrm{mg}$ of each sample in $10 \mathrm{ml}$ of acetic acid for $12 \mathrm{~h}$. Whole-rock syenites and silicate minerals were first decomposed in $4 \mathrm{ml} \mathrm{HF}$ and $2 \mathrm{ml} \mathrm{HNO}_{3}$, in Teflon digestion bombs during $48 \mathrm{~h}$ at $120^{\circ} \mathrm{C}$ and finally in $6 \mathrm{M} \mathrm{HCl}$. Elemental Rb, Sr, Sm and Nd in carbon- 
ates and silicates were determined by isotope dilution using spikes enriched in ${ }^{87} \mathrm{Rb},{ }^{84} \mathrm{Sr},{ }^{149} \mathrm{Sm}$ and ${ }^{150} \mathrm{Nd}$. Ion exchange techniques were used to separate the elements for isotopic analysis. Rb, Sr and REE were separated using Bio-Rad AG50 $\times 12$ cation exchange resin. $\mathrm{Sm}$ and Nd were further separated from the REE group using Biobeads coated with $10 \%$ HDEHP. All isotopic analyses were carried out on a VG Sector 54 multicollector mass spectrometer at the Geocronología y Geoquímica Isotópica Laboratory. Complutense University, Madrid, Spain. Isotope data are shown in Table 2. Errors in the initial ratios are reported at $2 \sigma$.

$\mathrm{U}-\mathrm{Th}-\mathrm{Pb}$ analyses were performed on two samples using SHRIMP II at the Research School of Earth Sciences, The Australian National University, Canberra. One was a euhedral zircon megacryst up to $1.5 \mathrm{~cm}$ in width, extracted from a syenite; the second was a hand-picked concentrate separated after milling another syenite. Zircon fragments were mounted in epoxy together with chips of the Temora reference zircon, ground approximately half-way through and polished. Reflected and transmitted light photomicrographs, and cathodo-luminescence (CL) SEM images, were used to decipher the internal structures of the sectioned grains and to target specific areas within the zircons. Eachanalysisconsisted of sixscans through the mass range. The data were reduced in a manner similar to that described by Williams (1998, and references therein), using the SQUID Excel Macro of Ludwig (2001). Data for the geochronology samples are given in Table 3.

\section{Geochemistry}

\subsection{Major and trace elements}

The syenitic rocks display a relatively wide, alkali-rich compositional range from nepheline monzosyenites $\left(52 \% \mathrm{SiO}_{2}\right)$ to normal syenites (58-64\% $\mathrm{SiO}_{2}$ ) (Table 1 and Fig. 4), and are Na-rich $\left(\mathrm{K}_{2} \mathrm{O} / \mathrm{Na}_{2} \mathrm{O} \mathrm{mol} \geq 0.33\right)$. They plot in the alkali and ferroan fields of the Frost et al. (2001) diagram, clearly indicating an alkaline signature for the parental magma (Fig. $4 \mathrm{~b}$ and c).

The $\mathrm{Zr}$ content of the suite is remarkably high (716-1920 ppm), consistent with experimental evidence indicating that $\mathrm{Zr}$ is more soluble in peralkaline than in metaluminous melts (Watson, 1979; Watson and Harrison, 1983). A negative correlation between $\mathrm{Zr}$ and Agpaitic Index (Fig. 5a) strongly suggests that the alkali content of the melt controlled the crystallization of zircon. Zircon saturation temperatures $\left(T_{\mathrm{Zr}}\right)$ calculated from bulk-rock compositions using the equations of Watson and Harrison (1983) and Miller et al. (2003), yield initial temperatures of crystallization between 826 and $1022^{\circ} \mathrm{C}$, similar to those recorded for basaltic magmas.

The syenitic suite shows a strong decrease in $\mathrm{P}_{2} \mathrm{O}_{5}, \mathrm{REE}_{\text {total }}, \mathrm{Sr}$ and $\mathrm{Y}$ with $\mathrm{SiO}_{2}$ (Fig. 6). REE patterns also change significantly with silica content, from $[\mathrm{La} / \mathrm{Yb}]_{\mathrm{N}}=26$ in the least evolved rock, to a $\mathrm{U}$-shaped pattern with $[\mathrm{La} / \mathrm{Yb}]_{\mathrm{N}}=2.33$ and a well-developed positive Eu anomaly in the most evolved one (Fig. 7a). $\mathrm{P}_{2} \mathrm{O}_{5}$ contents decrease from $0.74 \%$ (1.9\% normative apatite) in the least evolved syenite to $0.02 \%$ ( $0.05 \%$ normative apatite) in the most evolved one.

The REE pattern of the nepheline monzosyenite (MAZ-12110, Fig. 7a) might reasonably suggest control entirely by the modal content of apatite (Fig. 7b). However, the HREE distribution cannot be explained by fractionation of apatite alone, particularly in the rocks of intermediate composition, as the decreasing slope of the patterns suggests crystallization of a mineral phase with a high partition coefficient for HREE, such as zircon (Fig. 7a and b). As noted above, zircon is a conspicuous accessory mineral in the syenitic suite, with megacrysts up to a few $\mathrm{cm}$ in size.

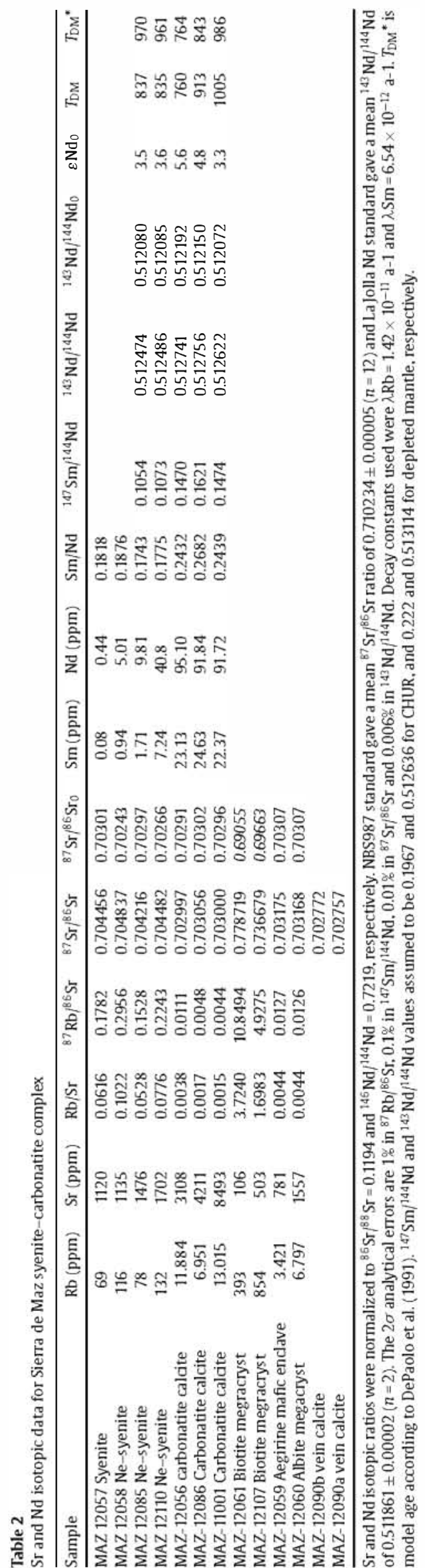


Table 3

U-PD SHRIMP data for zircon

\begin{tabular}{|c|c|c|c|c|c|c|c|c|c|c|c|c|c|c|}
\hline \multirow[t]{2}{*}{ Spot } & \multirow[t]{2}{*}{$\mathrm{U}(\mathrm{ppm})$} & \multirow[t]{2}{*}{ Th (ppm) } & \multirow[t]{2}{*}{ Th/U } & \multirow[t]{2}{*}{${ }^{206} \mathrm{~Pb}^{*}(\mathrm{ppm})$} & \multirow[t]{2}{*}{${ }^{204} \mathrm{~Pb} /{ }^{206} \mathrm{~Pb}$} & \multirow[t]{2}{*}{$\mathrm{f}_{206} \%$} & \multicolumn{4}{|l|}{ Total } & \multicolumn{2}{|l|}{ Radiogenic } & \multicolumn{2}{|l|}{ Age (Ma) } \\
\hline & & & & & & & ${ }^{238} \mathrm{U} /{ }^{206} \mathrm{~Pb}$ & \pm & ${ }^{207} \mathrm{~Pb} /{ }^{206} \mathrm{~Pb}$ & \pm & ${ }^{206} \mathrm{~Pb} / /^{238} \mathrm{U}$ & \pm & ${ }^{206} \mathrm{~Pb} /{ }^{238} \mathrm{U}$ & \pm \\
\hline \multicolumn{15}{|c|}{ Megacryst in syenite (MAZ-12089)d } \\
\hline 1 & 331 & 313 & 0.95 & 22.7 & 0.00011 & 0.21 & 12.5123 & 0.1391 & 0.0588 & 0.0005 & 0.0798 & 0.0009 & 494.6 & 5.4 \\
\hline 2 & 36 & 10 & 0.28 & 2.4 & 0.00018 & 0.02 & 12.9951 & 0.2427 & 0.0568 & 0.0019 & 0.0769 & 0.0015 & 477.8 & 8.8 \\
\hline 3 & 39 & 17 & 0.44 & 2.4 & 0.00099 & 0.64 & 13.8073 & 0.2510 & 0.0611 & 0.0023 & 0.0720 & 0.0013 & 448.0 & 8.1 \\
\hline 4 & 448 & 203 & 0.45 & 26.8 & 0.00006 & 0.16 & 14.3597 & 0.1565 & 0.0568 & 0.0005 & 0.0695 & 0.0008 & 433.3 & 4.6 \\
\hline 5 & 88 & 14 & 0.16 & 6.9 & - & 0.41 & 10.9412 & 0.1545 & 0.0622 & 0.0012 & 0.0910 & 0.0013 & 561.6 & 7.8 \\
\hline 6 & 22 & 5 & 0.23 & 1.7 & 0.00097 & 0.88 & 10.9459 & 0.2411 & 0.0659 & 0.0024 & 0.0906 & 0.0020 & 558.8 & 12.1 \\
\hline 7 & 595 & 486 & 0.82 & 38.3 & - & 0.19 & 13.3401 & 0.1427 & 0.0579 & 0.0004 & 0.0748 & 0.0008 & 465.1 & 4.9 \\
\hline 8 & 1115 & 1086 & 0.97 & 88.9 & 0.00002 & 0.05 & 10.7726 & 0.1118 & 0.0596 & 0.0003 & 0.0928 & 0.0010 & 571.9 & 5.8 \\
\hline 9 & 405 & 92 & 0.23 & 29.7 & 0.00005 & $<0.01$ & 11.6974 & 0.1293 & 0.0576 & 0.0005 & 0.0855 & 0.0010 & 529.0 & 5.7 \\
\hline 10 & 36 & 9 & 0.25 & 2.8 & 0.00090 & 0.54 & 11.0190 & 0.2023 & 0.0632 & 0.0018 & 0.0903 & 0.0017 & 557.1 & 10.1 \\
\hline 11 & 453 & 66 & 0.15 & 33.8 & 0.00001 & 0.16 & 11.5392 & 0.1260 & 0.0595 & 0.0006 & 0.0865 & 0.0010 & 534.9 & 5.7 \\
\hline 12 & 94 & 36 & 0.38 & 7.4 & 0.00023 & $<0.01$ & 10.9050 & 0.1517 & 0.0572 & 0.0011 & 0.0919 & 0.0013 & 566.8 & 7.7 \\
\hline 13 & 222 & 163 & 0.74 & 13.3 & 0.00042 & 0.33 & 14.3887 & 0.1729 & 0.0582 & 0.0008 & 0.0693 & 0.0008 & 431.7 & 5.1 \\
\hline 14 & 27 & 4 & 0.15 & 2.1 & 0.00135 & $<0.01$ & 10.9319 & 0.2272 & 0.0563 & 0.0023 & 0.0918 & 0.0020 & 566.0 & 11.6 \\
\hline 15 & 56 & 10 & 0.17 & 4.6 & 0.00033 & $<0.01$ & 10.4643 & 0.1678 & 0.0590 & 0.0024 & 0.0956 & 0.0016 & 588.8 & 9.4 \\
\hline 16 & 163 & 39 & 0.24 & 12.6 & 0.00003 & 0.17 & 11.0752 & 0.1378 & 0.0601 & 0.0009 & 0.0901 & 0.0011 & 556.4 & 6.8 \\
\hline 17 & 369 & 64 & 0.17 & 31.6 & 0.00009 & 0.12 & 10.0324 & 0.1116 & 0.0612 & 0.0006 & 0.0996 & 0.0011 & 611.8 & 6.6 \\
\hline 18 & 31 & 7 & 0.23 & 2.2 & 0.00143 & 0.59 & 11.9436 & 0.2403 & 0.0624 & 0.0021 & 0.0832 & 0.0017 & 515.4 & 10.2 \\
\hline 19 & 384 & 348 & 0.90 & 24.7 & 0.00017 & 0.26 & 13.3870 & 0.1725 & 0.0584 & 0.0006 & 0.0745 & 0.0010 & 463.2 & 5.8 \\
\hline 20 & 500 & 527 & 1.05 & 33.1 & 0.00007 & 0.10 & 12.9963 & 0.1410 & 0.0574 & 0.0005 & 0.0769 & 0.0008 & 477.4 & 5.1 \\
\hline \multicolumn{15}{|c|}{ Zircon grains from syenite sample MAZ-12057b } \\
\hline 1.1 & 132 & 31 & 0.23 & 9.6 & 0.00019 & 0.17 & 11.8406 & 0.1381 & 0.0592 & 0.0008 & 0.0843 & 0.0010 & 521.8 & 6.0 \\
\hline 2.1 & 156 & 63 & 0.41 & 12.3 & 0.00011 & $<0.01$ & 10.9227 & 0.1246 & 0.0589 & 0.0007 & 0.0916 & 0.0011 & 564.7 & 6.3 \\
\hline 3.1 & 51 & 11 & 0.22 & 4.2 & - & 0.19 & 10.5115 & 0.2263 & 0.0611 & 0.0018 & 0.0949 & 0.0021 & 584.7 & 12.3 \\
\hline 4.1 & 15 & 2 & 0.11 & 1.1 & 0.00084 & 0.25 & 11.7823 & 0.2423 & 0.0599 & 0.0026 & 0.0847 & 0.0018 & 523.9 & 10.6 \\
\hline 5.1 & 65 & 17 & 0.26 & 5.3 & 0.00009 & 0.04 & 10.5699 & 0.1380 & 0.0598 & 0.0011 & 0.0946 & 0.0013 & 582.5 & 7.4 \\
\hline 6.1 & 508 & 513 & 1.01 & 41.4 & 0.00003 & 0.04 & 10.5318 & 0.1107 & 0.0598 & 0.0004 & 0.0949 & 0.0010 & 584.5 & 6.0 \\
\hline 7.1 & 159 & 48 & 0.30 & 12.8 & - & 0.13 & 10.6742 & 0.1551 & 0.0603 & 0.0007 & 0.0936 & 0.0014 & 576.6 & 8.2 \\
\hline 8.1 & 82 & 25 & 0.31 & 6.5 & 0.00030 & 0.11 & 10.9082 & 0.1648 & 0.0599 & 0.0012 & 0.0916 & 0.0014 & 564.8 & 8.4 \\
\hline 9.1 & 226 & 117 & 0.52 & 18.5 & 0.00003 & $<0.01$ & 10.4898 & 0.1158 & 0.0594 & 0.0005 & 0.0954 & 0.0011 & 587.1 & 6.3 \\
\hline 10.1 & 28 & 5 & 0.17 & 2.1 & - & $<0.01$ & 11.8505 & 0.4234 & 0.0537 & 0.0015 & 0.0848 & 0.0031 & 524.8 & 18.3 \\
\hline 11.1 & 104 & 31 & 0.30 & 8.0 & 0.00024 & $<0.01$ & 11.1549 & 0.1404 & 0.0584 & 0.0008 & 0.0897 & 0.0012 & 553.6 & 6.8 \\
\hline 12.1 & 279 & 141 & 0.50 & 22.7 & 0.00000 & 0.04 & 10.5359 & 0.1144 & 0.0598 & 0.0005 & 0.0949 & 0.0011 & 584.3 & 6.2 \\
\hline 13.1 & 26 & 5 & 0.19 & 1.8 & 0.00043 & $<0.01$ & 12.5276 & 0.2281 & 0.0570 & 0.0024 & 0.0798 & 0.0015 & 495.1 & 8.9 \\
\hline 14.1 & 105 & 15 & 0.14 & 8.1 & 0.00020 & 0.09 & 11.1599 & 0.1388 & 0.0593 & 0.0011 & 0.0895 & 0.0011 & 552.7 & 6.7 \\
\hline 15.1 & 51 & 4 & 0.07 & 3.9 & 0.00012 & $<0.01$ & 11.1513 & 0.3850 & 0.0586 & 0.0018 & 0.0897 & 0.0032 & 553.6 & 18.7 \\
\hline 16.1 & 463 & 419 & 0.91 & 36.7 & - & 0.08 & 10.8333 & 0.1235 & 0.0597 & 0.0004 & 0.0922 & 0.0011 & 568.7 & 6.3 \\
\hline 17.1 & 70 & 20 & 0.29 & 5.8 & 0.00015 & $<0.01$ & 10.4887 & 0.1365 & 0.0584 & 0.0010 & 0.0955 & 0.0013 & 587.8 & 7.5 \\
\hline 18.1 & 270 & 129 & 0.48 & 21.5 & 0.00007 & $<0.01$ & 10.7867 & 0.1196 & 0.0582 & 0.0005 & 0.0928 & 0.0011 & 572.2 & 6.2 \\
\hline 19.1 & 453 & 420 & 0.93 & 35.9 & 0.00001 & 0.01 & 10.8307 & 0.1144 & 0.0591 & 0.0004 & 0.0923 & 0.0010 & 569.2 & 5.9 \\
\hline 20.1 & 142 & 66 & 0.47 & 11.0 & - & 0.20 & 11.0545 & 0.1292 & 0.0604 & 0.0007 & 0.0903 & 0.0011 & 557.2 & 6.4 \\
\hline 21.1 & 156 & 70 & 0.45 & 11.4 & 0.00004 & $<0.01$ & 11.7096 & 0.1355 & 0.0577 & 0.0007 & 0.0854 & 0.0010 & 528.4 & 6.0 \\
\hline 22.1 & 34 & 5 & 0.15 & 2.5 & 0.00062 & $<0.01$ & 11.3710 & 0.3692 & 0.0566 & 0.0016 & 0.0881 & 0.0029 & 544.5 & 17.3 \\
\hline 24.1 & 232 & 104 & 0.45 & 18.6 & 0.00005 & $<0.01$ & 10.7277 & 0.1192 & 0.0585 & 0.0006 & 0.0933 & 0.0011 & 575.0 & 6.2 \\
\hline 23.1 & 121 & 47 & 0.39 & 9.3 & 0.00003 & $<0.01$ & 11.1435 & 0.1583 & 0.0583 & 0.0008 & 0.0898 & 0.0013 & 554.2 & 7.7 \\
\hline 25.1 & 50 & 8 & 0.17 & 3.9 & - & $<0.01$ & 10.9988 & 0.1673 & 0.0583 & 0.0013 & 0.0910 & 0.0014 & 561.3 & 8.4 \\
\hline 26.2 & 84 & 19 & 0.23 & 6.7 & 0.00008 & $<0.01$ & 10.6714 & 0.1370 & 0.0587 & 0.0010 & 0.0938 & 0.0012 & 577.8 & 7.3 \\
\hline 11.3 & 98 & 29 & 0.29 & 7.1 & 0.00015 & $<0.01$ & 11.8105 & 0.1492 & 0.0569 & 0.0009 & 0.0848 & 0.0011 & 524.5 & 6.5 \\
\hline 27.1 & 71 & 17 & 0.24 & 5.5 & - & $<0.01$ & 11.0560 & 0.1478 & 0.0573 & 0.0011 & 0.0906 & 0.0012 & 559.2 & 7.3 \\
\hline
\end{tabular}

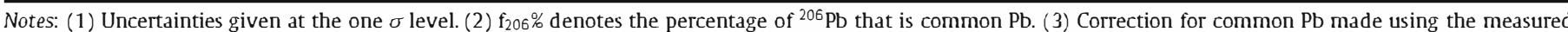
${ }^{238} \mathrm{U} /{ }^{206} \mathrm{~Pb}$ and ${ }^{207} \mathrm{~Pb} /{ }^{206} \mathrm{~Pb}$ ratios following Tera and Wasserburg (1972) as outlined in Williams (1998).

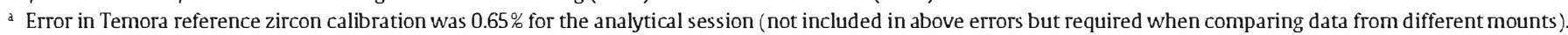

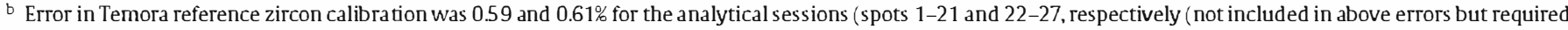
when comparing data from different mounts). Note that analyses 11.2 and 26.1 were not completed.

Coupled fractionation of apatite and zircon may replicate the observed REE patterns in the syenites of intermediate composition $\left(\mathrm{SiO}_{2}=58-61 \%\right)$. The depletion of REE in the most evolved syenites $\left(\mathrm{SiO}_{2}=64 \%\right)$ may be explained by the effective fractionation of accessory minerals, leaving plagioclase-rich residual liquids (Fig. 7a and b).

The two carbonatite samples (Table 1) are silico-carbonatites that have steep, LREE-enriched patterns with no Eu anomalies, and plot within the field defined for most world-wide carbonatites (Fig. 7c). They also contain large amounts of $\mathrm{Ti}, \mathrm{Nb}, \mathrm{Y}, \mathrm{Sr}$ and $\mathrm{Ba}$ (Table 1), as usually reported in carbonatite complexes (e.g., Culler and Graf, 1984). Compared with the carbonatite whole-rock REE patterns, the REE analysis by XRF of a relic large homogeneous crystal of calcite (Table 1, sample MAZ-12090), shows a parallel but slightly more enriched pattern (Fig. 7c). The REE pattern of the least evolved member of the syenitic suite (MAZ-12110) (Fig. 7a), has lower total REE content than associated carbonatites, but similar LREE/HREE ratios (Fig. 7c), a characteristic that has been reported in several alkaline-carbonatite complexes (e.g., Culler and Graf, 1984; Villenueve and Relf, 1998).

\section{7. $\mathbf{R b}-\mathrm{Sr}$ and $\mathrm{Sm}-\mathrm{Nd}$ isotope systematics}

The present-day Sr isotope compositions of the carbonatite calcite and vein calcite are similar and very unradiogenic (Table 2). The slightly higher ${ }^{87} \mathrm{Sr} /{ }^{86} \mathrm{Sr}$ values in the carbonatite calcite 

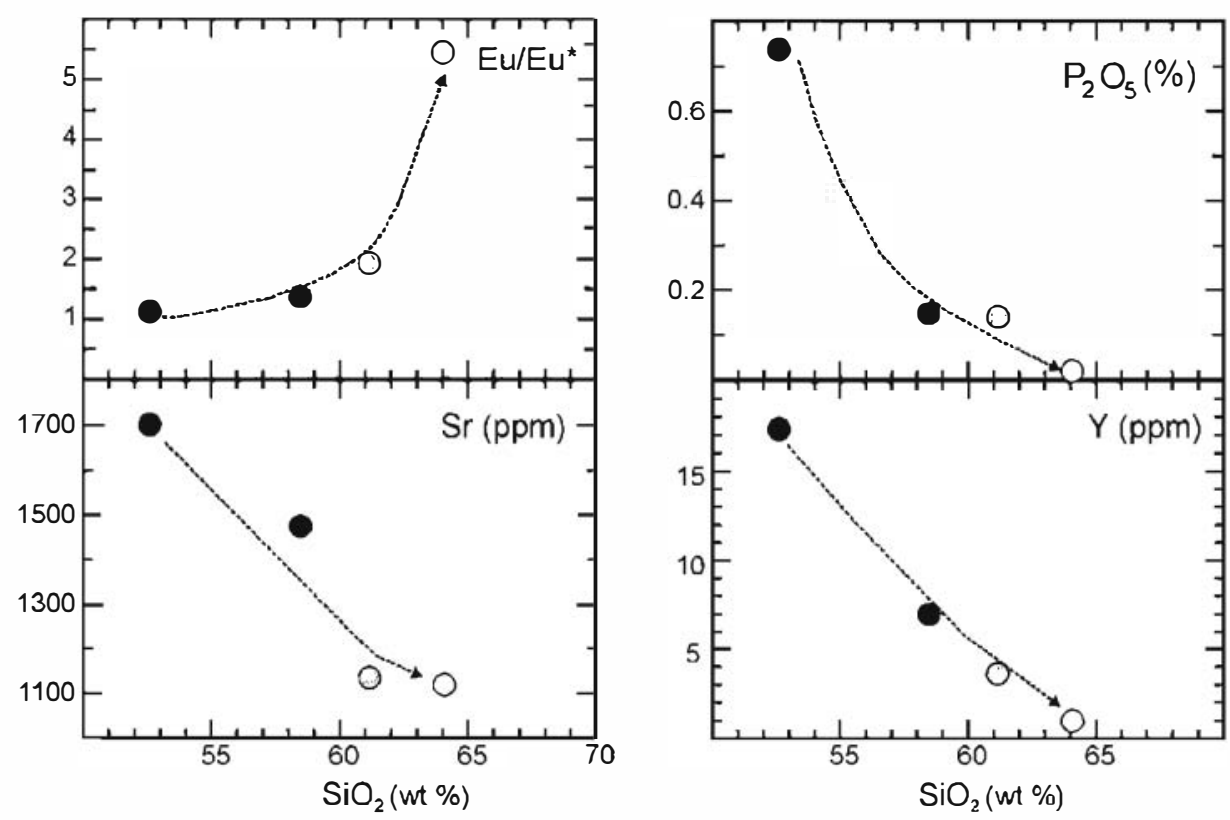

Fig. 6. $\mathrm{Eu} / \mathrm{Eu}^{*}, \mathrm{P}_{2} \mathrm{O}_{5}, \mathrm{Sr}$ and $\mathrm{Y}$ vs. $\mathrm{SiO}_{2}$ wt.\% for the syenitic suite of Sierra de Maz.

coloured zones are enriched in Th, $\mathrm{U}$ and REE and are poorer in Hf compared to the darker ones.

\subsection{Zircon megacryst}

One megacryst (MAZ-12089) was extracted in the field for initial study. Cathodo-luminescence (CL) images (Fig. 9b) show that it has a very complex internal structure. The oldest zircon in textural terms appears as internal areas of relatively uniform growth with low luminescence; there are also areas of higher luminescence and rather irregular alternating structure which are nevertheless relatively homogeneous. However, large irregular areas have variable luminescence with complex internal structure which appears to be secondary. Within the latter we distinguish areas of complex patchy texture, and areas in which highly luminescent microveins penetrate the old homogeneous zones, apparently resulting from replacement or recrystallization along cracks. Such complex textures are usually ascribed to late- or post-magmatic processes, including hydrothermal alteration, and metamorphism (see Corfu et al., 2003; Figs. 6-16, 10-5 and 11-7). Finally, there is one peripheral area with more regular oscillatory zoning that could represent newer growth.

SHRIMP U-Pb spot analysis (Table 3a) shows that the structural complexity corresponds to a large extent with variable isotope systematics. The total range of apparent ${ }^{206} \mathrm{~Pb}-{ }^{238} \mathrm{U}$ ages is 433-612 Ma, but most of the areas in relatively homogeneous domains yield ages of 530-590 Ma (e.g., Fig. 9b), with a single anomalous age of $612 \mathrm{Ma}$, whereas the mosaic areas generally yielded ages of $<500 \mathrm{Ma}$. The outer oscillatory-zoned domain also yielded younger ages of 450-495 Ma (spots 1, 2 and 3), clearly reflecting much later re-growth. Overall, there is no obvious correlation between age and either $U$ content or Th/U ratio. Eight results from the most homogeneous areas (spots 5, 6, 10, 12, 14, 14 and 16 in Table 3 ) gave a weighted mean age of $566 \pm 8 \mathrm{Ma}$ (MSWD 1.5) and three within the more complex areas (spots 9, 11 and 18) gave $530 \pm 19 \mathrm{Ma}$ (MSWD 1.4). These results are illustrated in a Tera-Wasserburg plot and a probability density diagram (Fig. 10a and $b$, respectively).

\subsection{Groundmass zircon}

Zircon extracted from whole-rock crushing of syenite MAZ12057 consists entirely of irregularly shaped grains up to $500 \mu \mathrm{m}$ in length of clear but heavily fractured zircon. The internal structure revealed by $\mathrm{CL}$ predominantly corresponds to the more homogenous type seen in the megacryst, albeit still with irregular cross-cutting zones with alternating structure (Fig. 9c). The absence of euhedral grains and the incomplete internal structures indicate that these grains are not individual crystals but fragments of larger grains, broken along internal fractures either in a geological event or during the mineral separation process. The latter is suggested by the occasional occurrence of mosaic patterned grains and is confirmed by examination of in situ zircon crystals in petrographic thin sections of other samples of the syenite (e.g., Fig. 9a) which show more complete zoned domains but extensive fractures.

The ${ }^{206} \mathrm{~Pb}-{ }^{238} \mathrm{U}$ ages obtained from the fragmented grains of MAZ-12057 (Table 3b) are similar to those from the more homogeneous domains of the megacryst, ranging from 495 to $588 \mathrm{Ma}$ (see Fig. 11a and b). Even this more limited range is well outside the analytical uncertainty of the individual results and encompasses a distribution that is at least bi-modal, twenty-two of the ages clustering around a broad peak at $571 \pm 5 \mathrm{Ma}$ (albeit with MSWD = 2.8) and a smaller group of five defining a weighted mean of $525 \pm 7 \mathrm{Ma}$ (MSWD $=0.2$ ) and a single age at $495 \mathrm{Ma}$. As with the megacryst analyses there is no obvious relationship between age and parameters such as $\mathrm{U}$ content or Th/U ratio.

\section{Discussion}

The Maz outcrop is an example of a deformed alkaline rock-carbonatite complex. Beyond its potential economic importance ( $\mathrm{Nb}, \mathrm{REE}$ ), this type of complex can be of value in constraining geodynamic and paleogeographic models of continental dispersal and amalgamation if the age of intrusion is defined.

\subsection{Chronological interpretation and geodynamic implications}

The Maz carbonatite-syenite was intruded into a Grenville-age basement that forms the central and eastern side of the sierra. The 


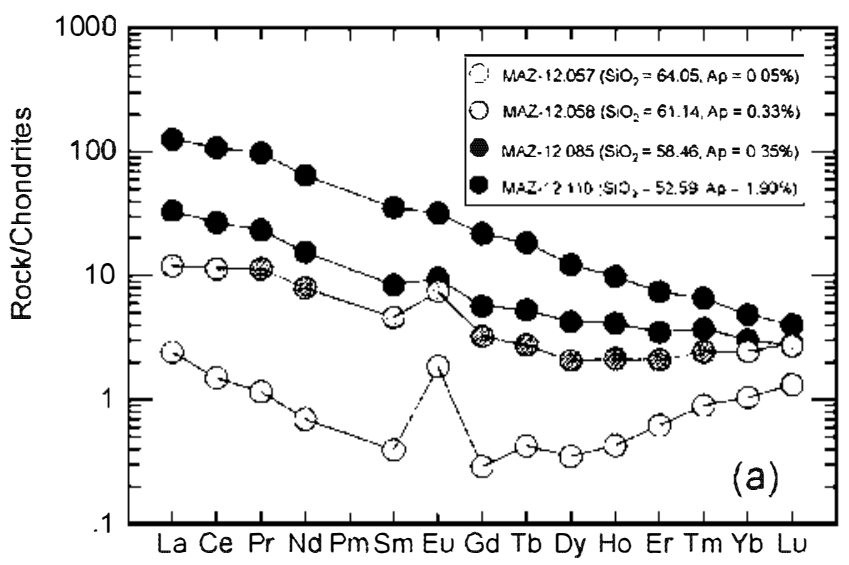

probable that the older zircon ages, yielding means of $566 \pm 7 \mathrm{Ma}$ in the case of the megacryst and $571 \pm 5 \mathrm{Ma}$ in that of the groundmass zircon, represent igneous crystallization during the Late Neoproterozoic. It is difficult to know whether the spread of the latter group indicated by the MSWD of 2.8 might signify more than one event; the most definitive statement that can be made concerning the age of this carbonatite complex is that it was emplaced within the interval 565-580 Ma, most probably at ca. 570 Ma, i.e., Ediacaran.

The $\mathrm{Rb}-\mathrm{Sr}$ whole rock systematics reinforce this interpretation; the two calculated isochron ages ( $582 \pm 60 \mathrm{Ma}$ and $565 \pm 60 \mathrm{Ma}$ ) are within error of the U-Pb zircon ages. The large uncertainties in these ages are due to the limited range of $\mathrm{Rb}-\mathrm{Sr}$ ratios, and this might lead to some doubts over the confidence of this result. However, we note that the whole-rock $\mathrm{Rb}-\mathrm{Sr}$ system in these rocks appears to have been resistant to disturbance during the amphibolice facies Famatinian metamorphism and deforma-
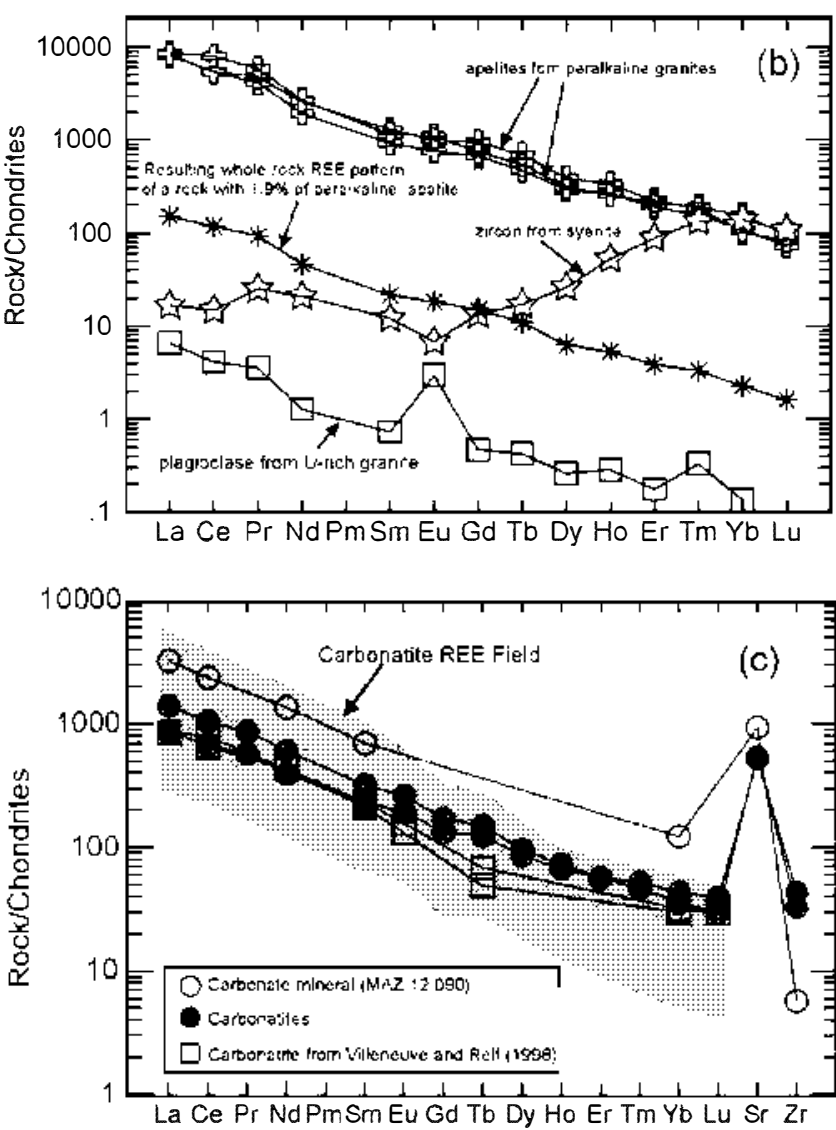

Fig. 7. (a) Chondrite-normalized REE abundances of the syenitic suite of the Sierra de Maz complex. (b) Selected REE patterns of apatite, zircon and plagioclase from alkaline rocks and U-rich granites, from Bea (1996). Note that a modelled REE pattern for a rock with $1.9 \%$ of normative apatite closely resembles the pattern of the least evolved member of the syenitic suite (sample MAZ-12110). (c) REE, Sr and Zr plot of two silico-carbonatite samples from the Sierra de Maz complex. The open circle represents a single homogeneous crystal of carbonate separated from the carbonatite. The general carbonatite field is taken from 13 samples reported by Nelson et al. (1988), whereas open squares are carbonatites reported by Villenueve and Relf (1998). Data are normalized to chondritic values of Nakamura (1974); other normalizing data from Boynton (1984) for Tb, Ho, Tm, and Sr and Thompson (1982) for $\mathrm{Zr}$.

local obliquity of the body to the regrional foliation and the fact that rotated blocks of the host gneisses are locally found in the carbonatite, logether with the zircon $\mathrm{U}-\mathrm{Pb}$ geochronological data presenced here, show that its emplacement age is post-Crenvillian. In the absence of any textural indication of inheritance, it is most

tion at ca. 430-440 Ma, which affected the whole region (Lucassen and Becchio, 2003; Casquet et al., 2005, 2008). A significantly older maximum possible age for the carbonacite syenice complex might be suggested by the Sm-Nd $T_{\mathrm{DM}}{ }^{*}$ model ages of $764-986 \mathrm{Ma}$, but in view of the fact that the whole-rock syerites do not yield a reasonable $\mathrm{Sm}-\mathrm{Nd}$ isochron, these seem as likely to reflect metamorphic disturbance of the $\mathrm{Sm}-\mathrm{Nd}$ systems in a carbonaterich environment, where REE are known to be relatively mobile (McLennan and Taylor, 1979; Banner et al., 1988). Alternatively, pre-crystallization Sm-Nd systematics may reflect some crustal contribution to the magma. Consequently we conclude that the Maz carbonatite-syenite complex is the first evidence of a Late Neoproterozoic rifting event in the Western Sierras Pampeanas.

In the case of the zircon megacryst it would be possible to interpret the few ages at $\sim 520 \mathrm{Ma}$ as due to partial Pb-loss. On the other hand, the well-defined age grouping at $525 \pm 7 \mathrm{Ma}$ given by zoned zircon in the whole-rock syenite, where Famatinian reworking is clearly minor (only one age of $<500 \mathrm{Ma}$ ), seems to indicate a specific event related to rejuvenation at the time of the Pampean orogeny ( Rapela et al., 1998b). The zoned zircon areas that yield this age are not rexturally distinguishable from the older zircon (there is certainly no evidence for any core-rim relationship indicacing re-growth), implying that these Pampean ages represent cryptic $\mathrm{Pb}-$-loss in a discrete event.

This interprecarion of the $\sim 525 \mathrm{Ma} \mathrm{U}-\mathrm{Pb}$ zircon ages may be taken as further evidence of the effects of the Early Cambrian Pampean orogeny in the Western Sierras Pampeanas. Until now most

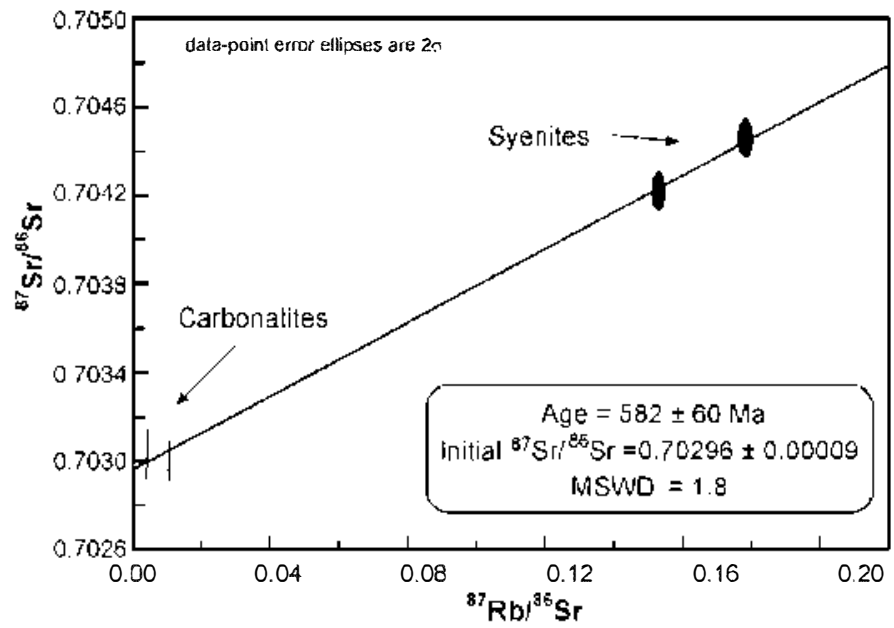

Fig. 8. $\mathrm{Rb}-\mathrm{Sr}$ isochron plot of whole-rock samples from the Maz carbonatite and syenite complex. 


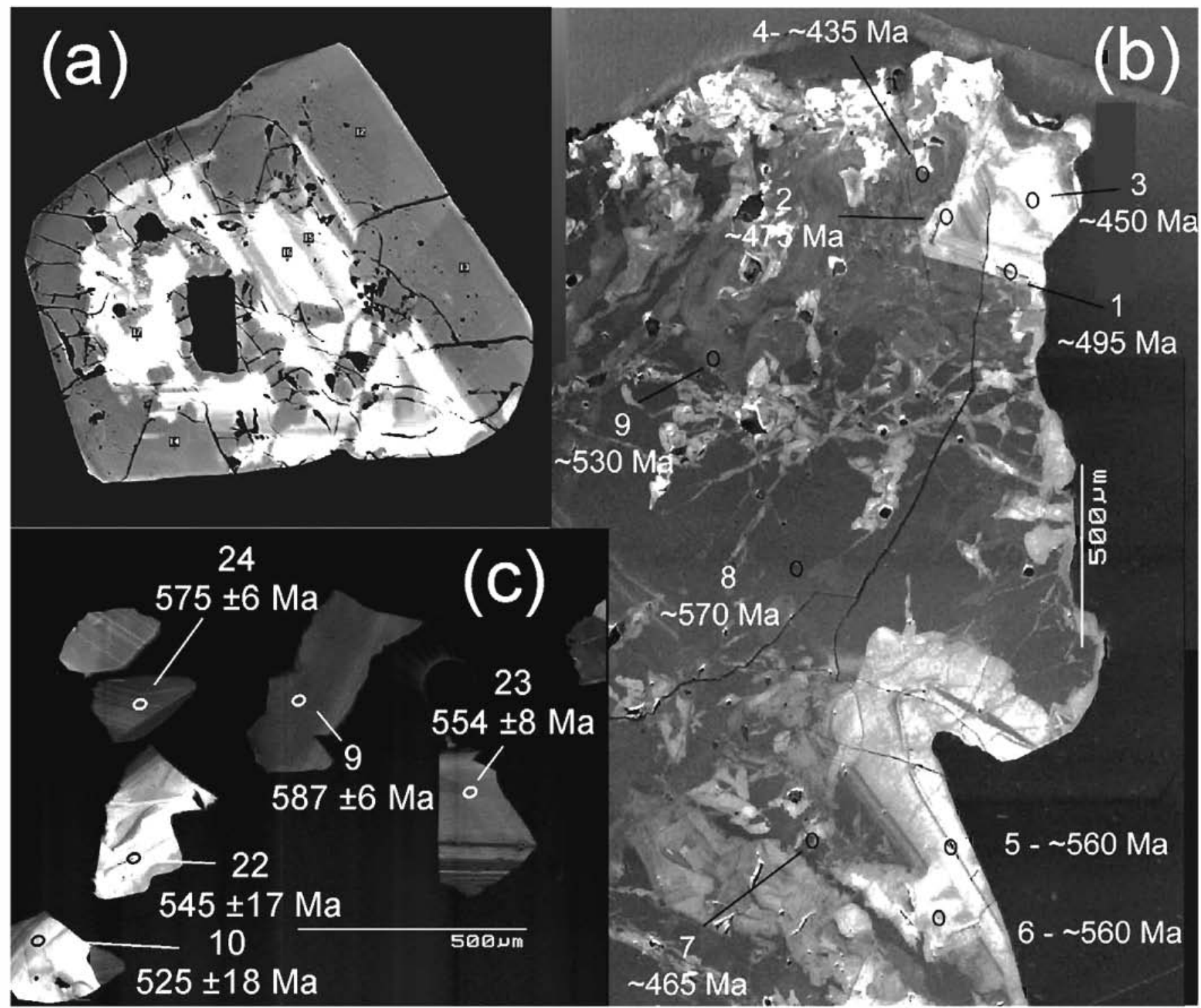

Fig. 9. (a) Back-scattered electron image of zircon in thin-section of syenite sample MAZ-12085, showing complex internal structure of a euhedral grain. NB in the latter image the dark areas are those relatively depleted in $U$ and REE, whereas in the CL images such composition results in high luminescence. (b) Cathodo-luminescence (CL) image of part of the analysed zircon megacryst from the Sierra de Maz syenite, showing the complex internal structure and the U-Pb ages determined from SHRIMP analyses. (c) CL image of typical fragmented crystals of zircon separated from syenite sample MAZ-12057, together with the U-Pb ages obtained from SHRIMP analyses.

reliable metamorphic ages in the Maz and Espinal area were either Grenville-age (ca. 1.2 Ga) or Famatinian (430-440 Ma, e.g., Lucassen and Becchio, 2003; Porcher et al., 2004; Casquet et al., 2005, 2006, 2008; and our unpublished data). Involvement of the Western Sierras Pampeanas Grenville-age basement in the Pampean orogeny has, however, been recently emphasized by Rapela et al. (2007). Recent determinations of a single U-Pb titanite age of ca. $530 \mathrm{Ma}$ from the southern tip of the Sierra de Maz (Lucassen and Becchio, 2003) and of a metamorphic hornblende $\mathrm{Ar}-\mathrm{Ar}$ age of $\mathrm{ca}$. $515 \mathrm{Ma}$ in the Grenvillian basement of the Sierra de Pie de Palo, south of Sierra de Maz (Mulcahy et al., 2007), strengthens this geodynamic interpretation.

According to the majority of the textural evidence, the younger ages of 433-495 Ma, particularly in the megacryst, are almost certainly related to minor zircon growth and variable Pb-loss, in part caused by invasive fluids penetrating along fractures, and would correspond to reactivation during Famatinian metamorphism. The highly fractured nature of the zircon megacryst would probably also have facilitated fluid exchange processes. Evidence for defor- mation and metamorphic rejuvenation under amphibolite facies conditions in the Maz and Espinal area at ca. 430-440 Ma has been shown by Lucassen and Becchio (2003), Porcher et al. (2004) and Casquet et al. (2005, 2008).

\subsection{Tectonic implications}

The rock association of alkali-syenite ( + nepheline) and carbonatite, with no evidence for associated alkali basalts shows that this is not a high-thermal anomaly mantle plume scenario, but was most probably related to an extensional environment. Vaughan and Scarrow (2003) suggested transtensional tectonics in a metasomatized mantle, but this produces K-rich magmas rather than Na-rich magmas responsible for the Sierra complex. Veevers (2003, 2007) suggested a similar mode of tectonic control for alkaline rocks and carbonatite (ARCs) emplaced during Gondwana amalgamation. However, although strike-slip was important during the Early Paleozoic assembly of this part of Gondwana (e.g., Rapela et al., 2007), the geochronological data presented here suggests that this 

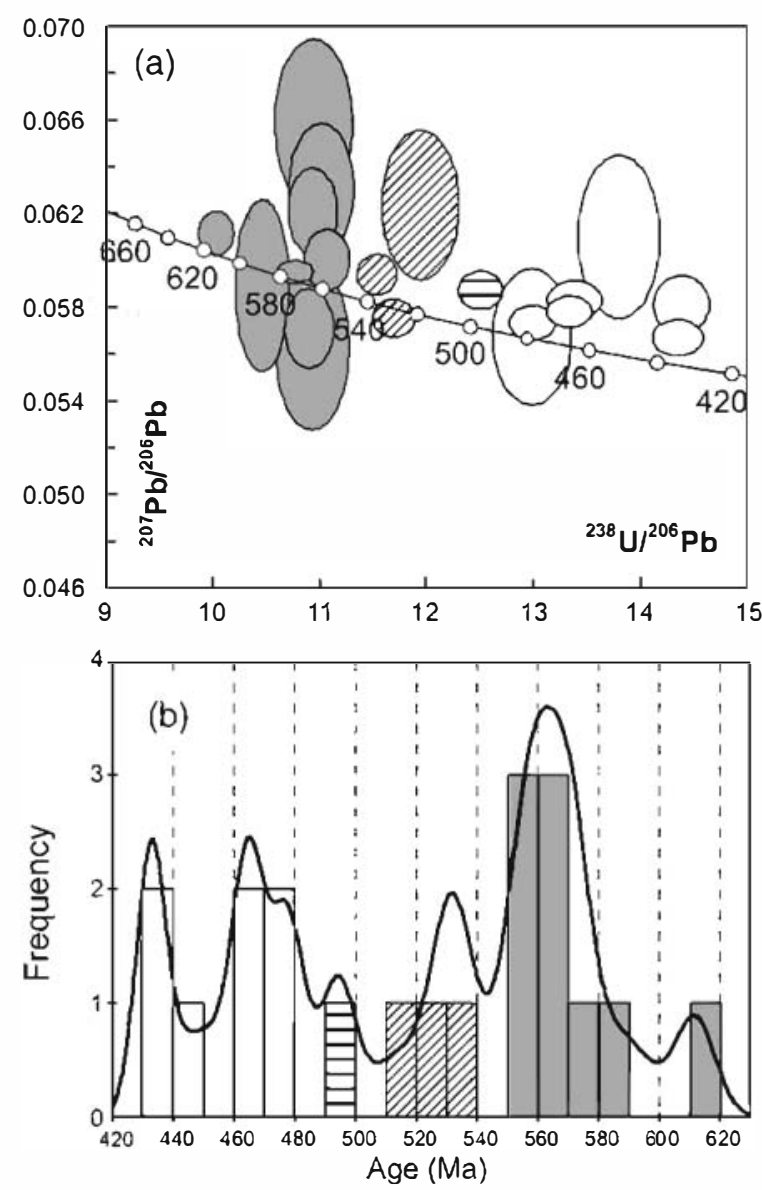

Fig. 10. (a) Tera-Wasserburg plot of U-Pb SHRIMP data for the zircon megacryst extracted from the syenite (Fig. 9b), error ellipses are $95 \%$ confidence limits. (b) Probability density plot (Ludwig, 1999) of ${ }^{207} \mathrm{~Pb}$-corrected ${ }^{206} \mathrm{~Pb}-{ }^{238} \mathrm{U}$ ages. Shading reflects groupings identified in the text.

complex was formed some 50 Ma before the mid-Cambrian Pampean orogeny, i.e., it was pre-orogenic. In particular, the weight of the U-Pb SHRIMP data does not support the idea of melting and crystallization of the syenite magma at $525 \mathrm{Ma}$, but merely suggests slight resetting at that time. We conclude that deepcontinental rifting in the Neoproterozoic rather than collisional tectonics was the likely cause of the alkaline-carbonatite magmatism, in accordance with conventional thinking on carbonatite generation (e.g., Bell et al., 1999).

\subsection{Paleogeographic implications}

The Grenville-age basement of Maz and Espinal, along with equivalent outcrops in the nearby Sierra de Umango (Fig. 1) (Varela et al., 2003), a Grenville-age ophiolite in the Sierra de Pie de Palo (Fig. 1) (Vujovich and Kay, 1998; Vujovich et al., 2004), and the northern part of the Arequipa-Antofalla craton in Peru were probably part of a continuous mobile belt of that age along the paleo-margin of the Amazonia craton (Casquet et al., 2008). This mobile belt has been considered as the result of collision between Amazonia and southernmost Laurentia, supposedly during the amalgamation of Rodinia (Wingate et al., 1998; Loewy et al., 2003, 2004; Tohver et al., 2002, 2004; Casquet et al., 2008).

Moreover, recent paleomagnetic evidence suggests that an ocean, i.e., the Clymene Ocean, existed at ca. $550 \mathrm{Ma}$ between the Amazonia craton on one side, and the Rio de la Plata, Kalahari and Australia cratons on the other (Trindade et al., 2006). Rapela et al.
(2007) have provided geological, geochemical and geochronological evidence that the Western Sierras Pampeanas Grenville-age basement was probably part of a larger continental mass that embraced the Amazonia craton, the Arequipa block of SW Peru, and other minor cratons by the time the Clymene Ocean existed. Furthermore, after consumption of the Clymene Ocean, this large continental mass underwent right-lateral (present coordinates) collision with other Gondwanan cratons to the east; e.g., collision with the Rio de la Plata and Kalahari cratons triggered the shortlived Pampean-Saldanian orogeny of Argentina and South Africa in the Early Cambrian (530-515 Ma; Rapela et al., 1998b, 2007)(Fig. 1).

Opening of the Clymene Ocean could not be older than ca. $570 \mathrm{Ma}$, the age of the youngest detrital zircons found in the sedimentary Puncoviscana Formation of the Eastern Sierras Pampeanas (Schwartz and Gromet, 2004; Rapela et al., 2007). This largely turbiditic sedimentary sequence of NW Argentina, was deposited along the Kalahari margin of the Clymene ocean and moved to its present position adjacent to the Rio de la Plata craton by rightlateral displacement during the Pampean collision (Schwartz and Gromet, 2004; Rapela et al., 2007). Rifting at ca. 570 Ma leading to opening of the Clymene Ocean is the most probable scenario for the intrusion of the Maz carbonatite-syenite complex (Fig. 12).

The western suture of the Pampean block has so far not been recognized probably because of strong Famatinian metamorphic overprint and Andean faulting throughout the Sierras Pampeanas, but it should lie somewhere between the Western Sierras Pampeanas and the easternmost Sierras de Córdoba (Fig. 1). The model
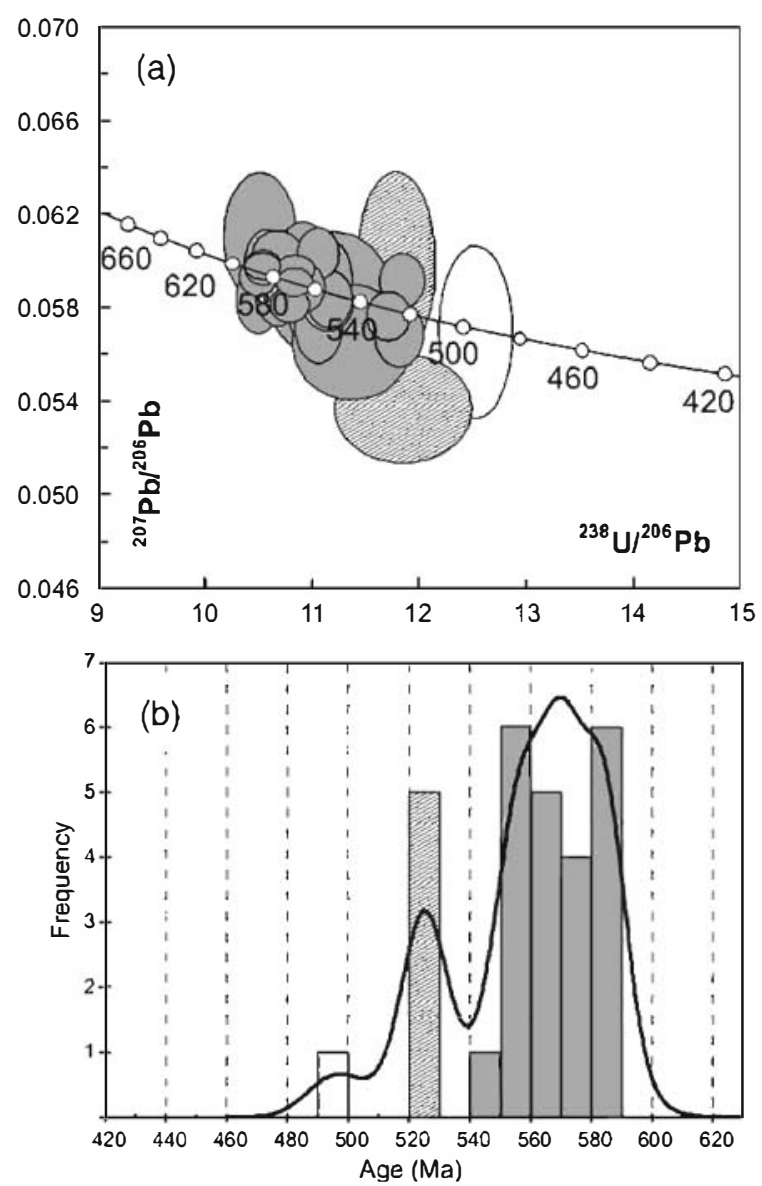

Fig. 11. (a) Tera-Wasserburg plot of U-Pb SHRIMP data for separated zircon from MAZ-12057 (Fig. 9c), error ellipses are 95\% confidence limits. (b) Probability density plot (Ludwig, 1999) of ${ }^{207} \mathrm{~Pb}$-corrected ${ }^{206} \mathrm{~Pb}-{ }^{238} \mathrm{U}$ ages. Shading reflects groupings identified in the text 
$550-540 \mathrm{Ma}$

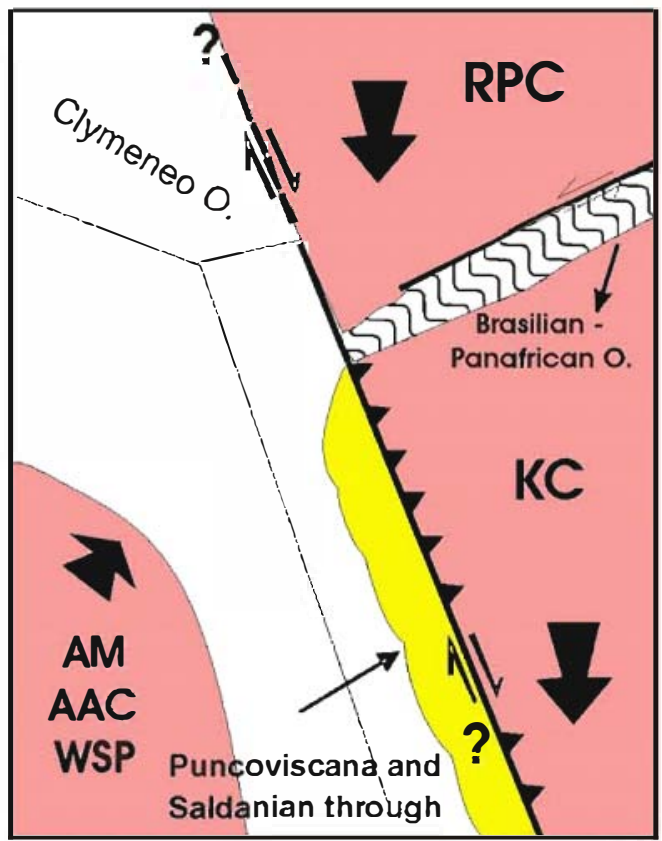

$540-520 \mathrm{Ma}$

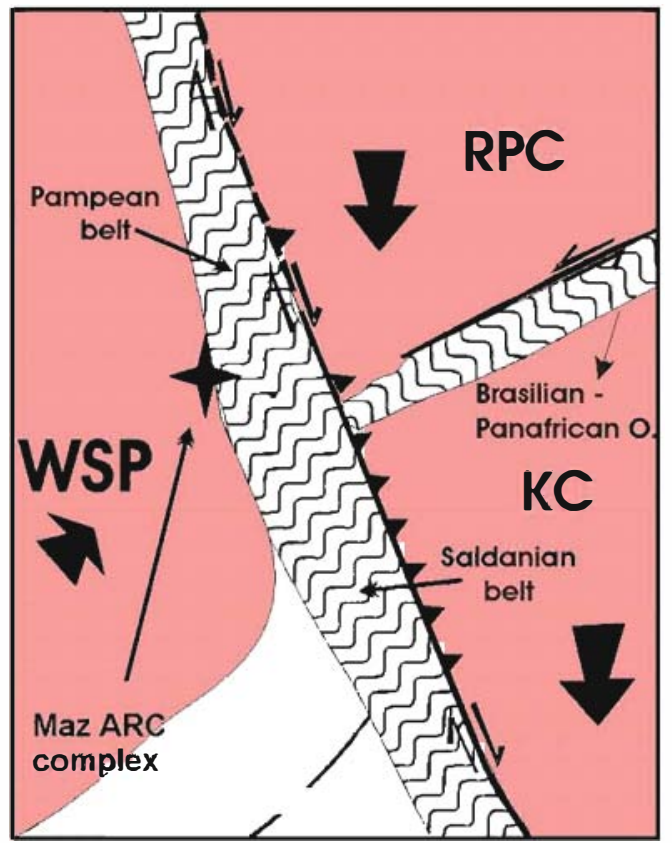

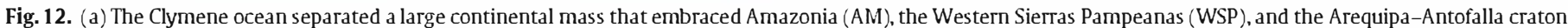

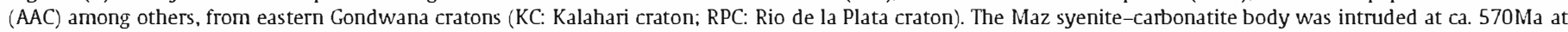

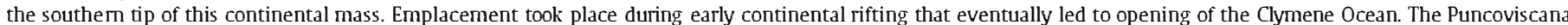

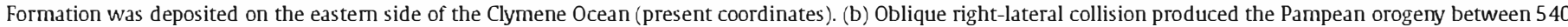
and 520 Ma. Paleogeographic model according to Rapela et al. (2007).

of DARC formation of Burke et al. (2003) and Burke and Khan (2006), according to which alkaline rock-carbonatite complexes formed at continental rifted margins at an early stage of a Wilson cycle and were finally entrapped near the suture after ocean closure and continent-continent collision, seems to apply here.

Nevertheless, the Pb-loss event recorded by some syenite zircons at ca. 525Ma support the idea that the Western Sierras Pampeanas basement was already joined to continental Gondwana to the east by Pampean times, i.e., before the supposed Ordovician arrival of the Precordillera terrane, and was therefore not exotic to it.

Reactivation of the Grenville-age basement during the Famatinian orogeny, involving regional metamorphism and fluid infiltration under amphibolite facies and ductile deformation, was responsible for the Pb-loss and overgrowths in zircons and probably also for the fabric shown by the Maz carbonatite-syenite body. The latter is suggested by the fact that annealing-recrystallization of calcite in carbonatite requires temperatures above ca. $500^{\circ} \mathrm{C}$ (Griggs et al., 1960). Pampean deformation, if any, is masked by Famatinian reworking.

\subsection{Implications for the magma source}

Low ${ }^{87} \mathrm{Sr} /{ }^{86} \mathrm{Sr}$ ratios and the very positive $\varepsilon \mathrm{Nd}_{570}$ values suggest that the carbonatite and syenite magmas were derived from a depleted mantle source. However, the two-stage $\mathrm{Nd}$ model ages $\left(T_{\mathrm{DM}}{ }^{*}\right)$ between 764 and $986 \mathrm{Ma}$ imply that contamination with a Nd-isotope component slightly less radiogenic than model depleted mantle at $570 \mathrm{Ma}$ was involved. The age of this source is likely to be Meso/Neoproterozoic and could correspond to a lower mafic continental crust strongly depleted in light REEs during granulite facies metamorphism at ca. $1.2 \mathrm{Ga}$ (Casquet et al., 2006). Petrographic, field, geochemical and geochronological evidence suggests that the carbonatite and syenite magmas were coeval. Common genesis of the less evolved syenitic magma and the carbonatites is also suggested by the parallel decrease in REE content with increasing $\mathrm{SiO}_{2}$ /carbonate ratio from carbonatite, to silico-carbonatite to melano-foid syenite (Fig. 7), observed also in other alkaline-carbonatite complexes (e.g., Villenueve and Relf, 1998). Chemical variation in the syenite probably arose by differentiation involving apatite and zircon among other phases, in a deep magma chamber prior to emplacement.

\section{Conclusions}

The deformed sodic syenite-carbonatite complex of the Sierra de Maz is recognized as a typical ARC in the sense of Burke et al. (2003), with very high concentrations of lithophile elements such as REE, Nb. Deformation may well be due to its involvement in the Early Paleozoic orogenies of the Sierras Pampeanas, but its probable emplacement age of close to $570 \mathrm{Ma}$ is consistent with Neoproterozoic lithospheric-scale rifting connected with the opening of the Clymene ocean during the break-up and dispersal of an earlier supercontinent such as Rodinia. This discovery may also have economic potential.

\section{Acknowledgements}

Financial support for this work was provided by Spanish MEC grants BTE2001-1486 and CGL2005-02065/BTE, Universidad Complutense grant PR1/05-13291 and Argentine public grants (FONCYT PICT 07-10735; CONICET PIP 5719; CONICET PEI-6275). R.J.P. acknowledges a NERC Small Research Grant. We are grateful to Kevin Burke, for suggestions based on an earlier draft of this paper and to D.L. Ashwal and an anonymous referee for their helpful comments to the manuscript. 


\section{Appendix A. Supplementary data}

Supplementary data associated with this article can be found, in the online version, at doi:10.1016/j.precamres.2008.06.011.

\section{References}

Ashwal, L.D., Armstrong, R.A., Roberts, R.J., Schmitz, M.D., Corfu, F., Hetherington, C.J., Buerke, K., Gerber, M., 2007. Geochronology of large zircons from nephelinebearing gneisses as constraints on tectonic setting: an example from southerm Malawi. Contrib. Mineral. Petrol. 153, 389-403.

Attoh, K., Corfu, F., Nude, P.M., 2007. U-Pb zircon age of deformed carbonatite and alkaline rocks in the Pan-African Dahomeyide suture zone, West Africa. Precambrian Res. 155, 251-260.

Bailey, D.K., 1977. Lithos pheric control of continental rift magmatism. J. Geol. Soc London $133,103-106$

Bailey. D.K., 1992. Épisodic alkaliue uctivity dcross Atrica: implicalions for tle causes of continental break-1p. In: Storey, B.C., Alabaster, A., Pankhurst, R.J. (Eds.) Magmatism and Causes Of Continental Break-Up. Geol. Soc. London, Special Publications, vol. 68, pp. 91-98.

Baldo, E., Casquet, C. Parkhurst, R.J., Galindo, C., Rapela, C.W., Fanning, C.M. Dahlquist, J., Murra, J., 2006. Neoproterozoic A-ty pe magmatism in the Western Sierras Pampeanas (Argentina): evidence for Rodinia break-up along a protoIapetus rift? Terra Nova 18, 388-394.

Banner, J.L. IIans on, G.N., Myers, W.J., 1988. Rare earth element and Nd isotopicvaridious iu tegioually exterssive dolomites from the Burlington-KeokukFormation : Mississippianj; implications for REE mobility during carbonate diagenesis. J. Sediuncut. Rcs. $\dot{8}, 41 b-432$

Bea, F., 1996. Residence of REE, Y, Th and U in granites and crustal protoliths; implications for the chesuistry of crustal melts. J. Petrol. 37,521-552.

Bell, K., 1989. Carbonatites: Geresis and Evolution. Unwin Hyman, London.

Bell, K., Kjarsgaard, B.A., Simonetti, A., 1999. Carbonatites; into the twenty-first century. J. Petrol. 39, 1839-1845.

Boyton, WV. 1984 Geochemiscry of the rare earth elements: meteorites studjes. In: Hedderson, P. i E.d. , Rare F.arth Element Geochemistry. Developments in Geochemistry, vol. 2. Elsevjer, Amsterdam, pp. 63-114.

Burke, K., Ashwal, L.D., Webb, S., 2003. New way to m.lp old sutures using deformed alkaline rocks and carbonatites. Geology 31, 391-394.

Burke, K., Khan, S., 2006. Geoinformatic approach to global nepheline syenite and carbonatite distribution: testing a Wilson cycle model. Geosphere 2, 53-60.

Casquet, C., Rupcli. C.W., Pankhurst, R.J., Galisdo. C., Dahlquist, J., Baldo, E.G., Saavedra, J., Gonzalez Casado, J.M., Fanning, C.M., 2005. Grenvillian massif type iltortlosites in the Sierras Pampeanas. J. Geol. Soc. London 162, 9

Casquet, C., Pankhurst, R.J., Fanning, C.M., Baldo, E., Galindo, C., Rapela, C.W., González-Casado, J.M., Dahlquist, J.A., 2006. U-Pb SHRIMP zircon dating of Grenvillian mecamorphisn in Western Sierras Pampeanas i Aroentina:: correlation with the Arequipa Antofalla craton and constraints on the extent of the Precordillera Terrane. Condwana Res. 9, 524-529.

Casquet, C. Pankhurst, RJ. Rapela, C. Galindo, C. Fanning C.M. Chiaradia, M. Baldo, E., González-Casado, J.M., Dahlquist, J.A., 2008. The Maz terrane: a Mesoproterozoic domain in the western Sierras Pampeanas (Argentina) equivalent to the Arequipa-Antofalla block of southern Peru? Implications for Western Gondwana margin evolution. Gondwana Res. 13, 163-175.

Corfu, F., Hanchar, J.M., Hoskin, P.W.O., Kinny, P., 2003. In: Hanchar, J.M., Hoskin, P.W.O. (Eds.), Atlas of Zircon Textures, vol. 53. Zircon. Rev. Mineral. Geochem. pp. 469-500.

Culler, R.L., Graf, J.L., 1984. Rare earth elements in igneous rocks of the continental crust: predominanty basic and ultrabasic rocks. In: Henderson, P. 'Ed. „, Rare Earth Element Geochemistry. Developments in Geochemistry, vol. 2. Elsevier, Amsterdam, pp. 237-274.

DePaolo, D.J., Linn, A.M., Schubert, G., 1991. The continental crustal age distribution: methods of determining mantle separation ages from Sm-Nd isotopic data and ap plication to the Southwestern United States. I. Geophys. Res. B96, 2071-2088

Frost, R.B., Barnes, C.G., Collins, W.J., Arculus, R.J., Ellis, D.J., Frost, C.D. 2001. A geochemical classification for granitic rocks. J. Petrol. 42, 2033 2048.

Galindo, C., Casquet, C., Rapela, C., Pankhurst, R.J., Baldo, E., Saavedra, J., 2004. Sr, C and $\mathrm{O}$ isotope geochemistry and stratigraphy of Precambrian aldd Lower Fule ozoic carbonate sequences from the Western Sierras Pampeanas of Argentina: tectonic implications. Precambrian Res. 131,55-71.

Griggs, D.T., Turner,F.J., Heard, H.C., 1960 . Deformation of rocks at 500 to $800^{\circ} \mathrm{C}$. GSA Mem. 79, 39-105.

Loewy, S.L., Connelly, J.N., Dalziel, I.W.D., Gower, C.F., 2003. Eastern Laurentia in Rodinia: constraints from whole-rock $\mathrm{Pb}$ and $\mathrm{U} / \mathrm{Pb}$ geochronology. Tectonophysics 375, 169-197.

Lowy, S.L. Connelly. I.N., Dalziel, I.W.D., 2004. An orphaned basement block: the Arequipa-Antofalla Basement of the central Andean margin of South America. CSA Bull. 116, 171-187.

Ludwig, K.R., 1999. Isoplot/Ex Version 2.31, a geochronological toolkit for Microsoft Excel. Berkeley Geochronological Center Special Publication, 1, Berkeley, CA 94709, USA. Special Publication, 2, Berkeley, CA 94709, USA

Lucassen, F., Becchio, R., 2003. Timing of high-grade metamorphism: early Palaeozoic U-Pb formation ages of titanite indicate long-standing high-T conditions at the western margin of Gondwana (Argentina, 26-29S). J. Metamorph. Geol. 21, 649-662.

McLennan, S.M., Taylor, S.R., 1979. Rare earth element mobility associated with uranium mineralisation. Nature 282, 247-250.

Middlemost, E., 1997. Magmas, Rocks and Planetary Development. A Survey of Magma/Igneous Rock Sys tems. Longman, London/New York, 299 pp.

Miller, C.F., Mc Dowell, S.M., Mapes, R.W., 2003. Hot and cold granites? Implications of zircon saturation temperatures and preservation of inheritance. Geology 31, 529-532.

Mulcahy, S.R., Roeske, S.M., McCleland, W.C., Nomade, S., Renne, P.R., 2007. Cambrian initiation of the Las Pirquitas thrust on the western Sierras Pampeanas, Argetstitua: isuplicitiosis lor tle tectonic evolution of the proto-Andean margin of South America. Geology 35, 443-446.

Nakamura, N., 1974. Detertuil istios of REE. Bd. Fc, Mg, Na and $\mathrm{K}$ in carbonaceous and ordinary chondrites. Geochim. Cosmochim. Acta 38, 757-775.

Nelson, D.R., Chivas, A.R., Chappell, B.W., McCulloch, M.T., 1988. Geochemical and isocoplic systematics in carbonatite and implications for the evolution of oceitu-jsldud sources. Geochim. Cosmochim. Acta 52, 1-7.

Porcher, C.C., Fernandes, L.A.D., Vujovich, G.I., Chernicoff, C.J., 2004. Thermobarometry, $\mathrm{Sm} / \mathrm{Nd}$ ages and geophysical evidence for the location of the suture zone between Cuyania and Pampia terranes. In: Vijovich, G.I., Fernandes, L.A.D., Ramos, V.A. (Eds.), Cuyania: A n Exotic Block to Gondwand. Gondwana Res., vol. 7. pp. 1057-1076

Ramos, V.A., 2004. Cuyania, an exotic block to Gondwana: review of a historical success and the presest probletss. In: Vujovich, G.I., Fernandes, LA.D., Ramos, V.A. iEds, ; Cuyania: An Exotic Block to Gondwana. Gondwana Res., vol. 7, pp. $100 \Omega-1026$.

Rapela, C.W., Pankhurst, R.J., Casquet, C., Baldo, E., Saavedra, J., Galindo, C., Fanning, C.M. (1998). The Pampean orogeny of the southern proto-Andes: Cambrian continental collision in the Sierras de Córdoba, in: Pankhurst, R.J., Rapela, C.W. (Eds.) The Proto-Andean Margin of Gondwana. Geol. Soc. London, Special Publications, vol. 142,pp. 181-217.

Rapela, C.W., Pankhurst, R.J., Cosquet, C., Baldo, E., Saavedra, J., Galindo, C., 1998b. Early evolution of the proto Anden margin of South America. Geology 26, 707-710.

Rapela, C.W., Casquet, C., Baldo, E., Dahlquist, J., Pankhurst, R.J., Galindo, C., Saavedra, J., 2002. Orogénesis del Paleozoico Inferior en el margen protoandino de Gondwana. Siesras Pampeanas Argentina. J. Merian Geol. 27. $23-41$.

Rapela, C.W., Pankhurst, R.J., Casquet, C., Fatıliug, C.M., Galitılo, C.. Baldo, E., 2005. Datación U-Pb SHRIMP de circones detríticos en para-anfibolitas neoproterozoicas de la secuencia Difunta Correa (Sierras Pampeanas Occidentales, Argentina ). Geogaceta 38, 227-230.

Rapela, C.W., Patıklırst. R.J., Casquet, C., Fanning, C.M., Baldo, E., Gonzalez-Casado, J.M., Galindo, C., Dahlquist, J.A., 2007. The Río de La Plata craton and the assembly of SW Gondwana. Earth-Sci. Rev. 83, 49-82.

Schwartz, J.J., Gromet, L.P., 2004. Provenance of Late Proterozoic-early Cambrian basin, Sjercas de Córdoba, Argentina. Precambrian Res. 129, 1-21.

Schultz, F., Lehmann, B., Tawackoli, S., Rossling, R., Belyatsky, B., Dulski, P., 2004 Carbonatite diversity in the Central Andes: the Ayopaya alkaline province, Bolivia. Contrib. Mineral. Petrol. 148, 391-408.

Thomas, W.A., 1991. The Appalachian-Ouachita rifted margin of s outheas tern North America. GSA Bull. 103, 415-431.

Thomas, W.A., Astini, R.A., 1996. The Argentine Precordillera: a traveler from the Ouachita cunbayucut of Nortl Anerica Laurentia. Science 273, 752-757.

Thomas, W.A., Astiri, R.A., 2003. Ordovician accretion of the Argentine Precordillera terrane to Gondwana: a review. J. South Am. Earth Sci. 16, 6779.

Thompson. R.N., 1982. British Tertiary wolcaric province. Scotosh J. Geol. I8, 49-1u7.

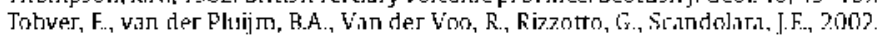
Paleogeography of the Amazon craton at $1.2 \mathrm{Ga}$ : early Grenville collision with the llano sepment of Lutrentia. Farth Planet Sci. Lett 199, 185200

Tohver, E.. Bettencourc 1.S., Tos da], R. Mezger, K., Leice, W.B., Payolla, B.L., 2004. Tertane transfer during the Grenville orogeny: tracis the Amazoni.ur ancestry of southem Appalachian bas ement through Pb and Nd isotopes. Earth Planet Sci. Lett. $228,161-1 \% 6$.

Trindade, R.I.F., DYAgrell a-Filho, M.S., E pof, I., Brito Neves, B.B., 2006. Paleomagnetism of Early Cambrian Itabaiana mafic dikes (NE Brazil) and the final assembly of Gondwana. Earth Planet Sci. Lett. 244, 361-377.

Varela, R., Sato, A., Bassei, M.A.S., Siga Jr., O., 2003. Proterozoico Inedio y Puleozoico inferior de la Sierra de Umango, antepais andino (29॰ S), Argentina: edades U-Pb y caracteristicas isotópicas. Revista Geol. Chile 30, 265-284.

Vaughan, A.P.M., Pankhurst, R.J., 2008. Tectonic overview of the West Gondwana margin. Gondwana Res. $13,15 \mathrm{U}-16$ ?

Vaughan, A.P.M., Scarrow, J.H., 2003. K-rich mantle metasomatism control of localization and initiation of lithos pheric strike-slip faulting. Terra Nova 15, 163-169.

Veevers, J.J., 2003. Pan-African is Pan-Gondwanaland: oblinue corvergence drives rotation durino 650-500Ma assembly. Geology 31,501-5ij4

Veevers, J.J., 2007. Pan-Gondwanaland post-collisional extension marked by 650-500Ma alkaline rocks and carbonatites and related detrital zircons: a review. Earth-Sci. Rev. 83, 1-47. 
Villenueve, M.E., Relf, C., 1998. Tectonic setting of 2.6 Ga carbonatites in the Slave Province, NW Canada. J. Petrol. 39, 1975-1986.

Vujovich, G.I., Kay, S.M., 1998. A Laurentian? Grenville-age oceanic arc/back-arc terrane in the Sierra de Pie de Palo, Western Sierras Pampeanas, Argentina. In: Pankhurst, R.J., Rapela, C.W. (Eds.), The Proto-Andean margin of Gondwana. Geol. Soc. London, Special Publication, 142, pp. 159-180.

Vujovich, G.I., Van Staal, C.R., Davis, W., 2004. Age constraints and the tectonic evolution and provenance of the Pie de Palo complex, Cuyania composite terrane, and the Famatinian orogeny in the Sierra de Pie de Palo, San Juán, Argentina. Gondwana Res. 7, 1041-1056.

Watson, E.B., 1979.Zircon saturation in felsic liquids: experimental res ults and applications to traceelement geochemistry. Contrib. Mineral. Petrol. 70, 407-419.
Watson, E.B., Harrison, T.M., 1983. Zircon saturation revisited: temperature and composition effects in a variety of crustal magma types. Earth Planet Sci. Lett. 64 $295-304$.

Williams, I.S., 1998. U-Th-Pb geochronology by ion microprobe. In: McKibben, M.A., Shanks III, W.C., Ridley, W.I. (Eds.), Applications of Microanalytical Techniques to Understanding Mineralizing Processes, Rev. Econ. Geol., vol. 7, pp. $1-35$.

Wingate, M.T.D. Campbell, IH, Compston, W. Gibson, G.M., 1998. Ion microprobe U-Pb ages for neoproterozoic-basaltic magmatism in south-central Australia and implications for the breakup of Rodinia. Precambrian Res. 87, $135-159$. 